[Vol. 129:302

\title{
MULTI-PARTY FORUM SHOPPING FOR APPELLATE REVIEW OF ADMINISTRATIVE AGTION
}

\author{
Thomas O. McGarity $\dagger$
}

\section{TABLE OF GONTENTS}

I. Forum Shopping-An Analysis of the Problem ..... 307

A. Varieties of Forum Shopping ............ 307

B. The Policies For and Against Forum Shopping ..... 312

1. Disadvantages of Forum Shopping ......... 312

a. Public Image of Lawyers and Courts ....... 312

b. Judicial Comity ................... 313

c. Uniform Application of Agency Policy ....... 314

d. Business Uncertainty .............. 317

e. Costs of Forum Shopping ............. 318

2. The Advantages of Forum Shopping ........ 318

II. Gurrent Practice Under Sectron 2112(a) ........ 319

A. The Cost of the Race ................. 322

B. The Fairness of the Race .............. 323

C. The Starting Pistol ................. 325

D. The Scope of the Agency Action ........... 328

1. Single Agency Action .............. 328

2. Successive Agency Actions ............. 329

$\uparrow$ Professor of Law, University of Texas. B.A. 1971, Rice University; J.D. 1974, University of Texas.

An earlier version of this Article was prepared as a report to the Administrative Conference of the United States. The views expressed herein are, however, the author's own and not necessarily those of any member of that agency or its advisory committees.

The author would like to express his appreciation to Professors Craig, Gottlieb, Kissam, Pierce, Schroeder and Shapiro of the University of Kansas School of Law, Charles Alan Wright of the University of Texas School of Law, William Allen of Covington and Burling, and Linda Sedivek of the Administrative Conference of the United States for their helpful comments on an earlier draft of this Article and to Janice Jacobs, Class of 1981, University of Kansas School of Law for her research assistance. 
E. Discretionary Transfer ................ 332

1. Convenience of the Parties ............. 333

2. Regional Impact of the Agency Action ........ 334

3. Comparative Aggrievement ............ 334

4. Same or Similar Proceedings in Another Circuit .. 396

F. Temporary Stays .................... 342

G. Simultaneous Filings ................. 343

III. Suggestions for REFORM $\ldots \ldots \ldots \ldots \ldots \ldots \ldots \ldots \ldots, 345$

A. The Need for Reform ................. 345

B. Patch and Repair ..................... 348

1. Judicial Patch and Repair ............. 348

a. Penalties for Racing ................ 348

b. Uniform Judicial Adherence to the Doctrine of Controlling Decision ............... 350

c. More Frequent Supreme Court Review of Intercircuit Conflicts .................. 351

d. Simultaneous Filings .............. 352

2. Agency Patch and Repair ............ 353

G. Statutory Reforms ................... 355

I. Mechanisms for Eliminating Forum Shopping ... 356

a. Exclusive Venue in a Particular Court ....... 356

b. Exclusive Venue in the Courts of the "Affected Regions" ..................... 360

2. Managing Forum Shopping ........... 362

a. Discretionary Mechanisms: The Multi-district Panel Proposal ................... 362

b. Discretionary Mechanisms: Transfer Criteria .. 365

(i) Judicial Expertise .............. 365

(ii) Pendency of Same or Similar Proceeding 367

(iii) Comparative Aggrievement ......... 367

(iv) Regional Nature of the Problem ...... 370

(v) Convenience of the Parties .......... 370

(vi) Convenience of the Courts ......... 370

c. Automatic Mechanisms ............... 371

IV. Conclusion $\ldots \ldots \ldots \ldots \ldots \ldots \ldots \ldots \ldots \ldots \ldots \ldots \ldots \ldots$ 
Judicial review of administrative action is a keystone of the American public law system. In individual agency statutes and in the Administrative Procedure Act ${ }^{1}$ (APA) Congress has given the federal appellate courts jurisdiction to review agency actions on both substantive and procedural grounds. ${ }^{2}$ The APA, however, does not specify a particular court for review, ${ }^{3}$ and the venue provisions of individual agency statutes commonly allow for review in several possible circuits. ${ }^{4}$ Understandably, an attorney will attempt to secure judicial review in the circuit in which his or her client will have the greatest chance for success. ${ }^{5}$ In multi-party proceedings that result in multiple appeals to different circuits there must be a mechanism for determining which court shall hear the case.

Under 28 U.S.C. $\$ 2112(a)$, the agency must file the record of the proceedings in the circuit in which the first petition was filed. ${ }^{6}$

1 Ch. 324, 60 Stat. 237 (1946) (codified in scattered sections of 5 U.S.C.).

2 The APA gives appellate courts the power to "hold unlawful and set aside" the results of formal rulemakings and adjudications that are "unsupported by substantial evidence" and the results of informal rulemakings that are "arbitrary, capricious, an abuse of discretion, or otherwise not in accordance with law." 5 U.S.C. $\$ 706(2)(A),(E)(1976)$. The appellate courts also have the power to set aside agency action that is "contrary to constitutional right, power, privilege, or immunity; ... in excess of statutory jurisdiction, authority, or limitations, or short of statutory right; [or] without observance of procedure required by law." Id. $\S 706(2)$ (B)(D).

3 The APA provides for judicial review in "a court specified by statute" or, if none is specified, in "[any] court of competent jurisdiction." 5 U.S.C. $\$ 703$ (1976). This Article will address only direct review of agency action by the United States courts of appeals. The vast array of agency actions that are reviewable in the first instance in federal district courts will not be studied here. Obviously, forum shopping opportunities arise in that context also to the extent that venue statutes are loosely drawn. For an excellent discussion of relative advantages of district court review versus direct appellate court review, see Currie \& Goodman, Judicial Review of Federal Administrative Action: Quest for the Optimum Forum, 75 Colum. L. Rev. 1, 39-61 (1975).

4 See 15 C. Wright, A. Mtrler \& E. Cooper, Federal Practice and ProGEDURE $\$ 3816$, at 102 n.4 (1976) [hereinafter cited as WRIGHT \& MnLER]; 16 id. $\$ 3941$, at 305-08 nn.1-59 (citing statutory provisions for review in the United States courts of appeals); Comment, Venue of NLRB Orders: An Invitation to Forum Shopping?, 8 StaN. L. Rev. 472 (1956). Special venue provisions are not uncommon. See, e.g., Clean Air Act $\$ 307$ (b), 42 U.S.C.A. $\$ 7607$ (b)(1) (Supp. 1980) (providing for review of certain national standards only in the District of Columbia Circuit).

5 See Comment, supra note 4, at 476 ; note 42 infra.

${ }^{6}$ If proceedings have been instituted in two or more courts of appeals with respect to the same order the agency, board, commission, or officer concerned shall file the record in that one of such courts in which a proceeding with respect to such order was first instituted. The other courts in which such proceedings are pending shall thereupon transfer them to the court of appeals in which the record has been filed. For the convenience of the parties in the interest of justice such court may thereafter transfer all the proceedings with respect to such order to any other court of appeals.

28 U.S.C. $\$ 2112$ (a) (1976). Section 2112 (a) on its face applies only to administrative "orders," and not to "rules." This raises the possibility that the section 
Because the filing rules in the courts of appeals generally allow a petitioner to file terse and largely uninformative petitions for review, the "first-to-file" rule of section 2112(a) and modern communications technology have combined to precipitate wild and often bizarre races to the courthouse. The winner is often determined by the agency's perceptions of the athletic prowess of competing counsel. $^{8}$ The inflexibility of the first-to-file rule is softened somewhat by a statutory provision that allows the court in which the petition was first filed to transfer the proceedings to another circuit court of appeals "[f]or the convenience of the parties in the interest of justice." 9 Courts have also spoken of their "inherent power" to transfer. ${ }^{10}$ In deciding whether to order discretionary transfer the courts have considered many factors, including the presumed convenience of the parties, ${ }^{11}$ the existence of ongoing proceedings involving the same or similar issues in other circuits, ${ }^{12}$ the relative aggrievement of the parties, ${ }^{13}$ and whether the agency action has a "regional impact." 14 Although the court of first filing normally hears the case, ${ }^{15}$ a court will occasionally transfer, even to a circuit in which no petition for review has been filed. ${ }^{16}$

Unfortunately, agency and courthouse clocks have not kept pace with modern communications technology. In an increasing number of cases competing petitions have been filed virtually simultaneously. Several recent agency regulations, which specify a precise time at some future date at which rules become final for

was intended to address only the final product of agency "adjudications," and not of "rulemakings." See Currie, Judicial Review Under Federal Pollution Laws, 62 Iowa L. Rev. 1221, 1264-65 n.298 (1977). The courts, however, have not hesitated to apply $\$ 2112(a)$ to rules as well as orders, and this Article will assume that no such distinction was intended. See, e.g., Southland Mower Co. v. CPSC, 600 F.2d 12 (5th Cir. 1979); Westinghouse Elec. Corp. v. NRC, 598 F.2d 759 (3d Cir. 1979); United Steelworkers v. Marshall, 592 F.2d 693 (3d Cir. 1979); BASF Wyandotte Corp. v. Costle, 582 F.2d 108 (1st Cir. 1978); Industrial Union Dep't v. Bingham, 570 F.2d 965 (D.C. Cir. 1977).

7 See, e.g., FED. R. App. P. 15(a); id. Form 3.

8 See, e.g., Tenneco Oil Co., Findings of Fact, Pursuant to Court Order, Concerning Filings of Petitions for Review of FERC Opinion Nos. 10 and 10-A, FERC Docket Nos. CI75-45, et al. (March 28, 1979); text accompanying notes 91-103 infra.

928 U.S.C. $\$ 2112(\mathrm{a})$ (1976).

10 See cases cited in note 88 infra.

11 See text accompanying notes 153-58 infra.

12 See text accompanying notes 128-49 \& 169-200 infra.

13 See text accompanying notes 162-68 infra.

14 See text accompanying notes 159-61 infra.

15 See note 89 infra.

16 See United Steelworkers v. Marshall, 592 F.2d 693 (3d Cir. 1979). 
purposes of judicial review, should greatly multiply the number of such simultaneous filings. ${ }^{17}$ These cases raise the threshold question of which court should determine who won the race or, in the absence of any definitive mechanism for resolving that question, the appropriate forum for a hearing on the merits. The courts apparently decide this threshold question through informal private telephone communications among the judges of the affected circuits. ${ }^{18}$ The designated court then either remands to the agency for further factfinding on the race issue ${ }^{19}$ or decides which forum is appropriate under the "convenience of the parties in the interest of justice" test.

The experience of the agencies, lawyers, and courts under section 2112 (a) raises two important questions. First, is forum shopping in the context of multi-party appeals an appropriate activity for lawyers to engage in? Second, assuming forum shopping cannot or should not be avoided, is the section 2112(a) first-to-file rule the most appropriate way of regulating that activity? This Article concludes that forum shopping probably cannot and should not be avoided entirely. Virtually every rule that can be imagined for discouraging forum shopping can be avoided by imaginative counsel, and the multi-circuit review that results from forum shopping can aid the Supreme Court in performing its review functions. The first-to-file rule and its accoutrements, however, are definitely not the most appropriate mechanism for choosing among the available appellate courts. The Article suggests several alternative mechanisms and ultimately concludes that a simple automatic assignment mechanism, such as a lottery, would be greatly preferable to the current rule.

17 See Environmental Protection Agency, Judicial Review Under Clean Water Act; Races to the Courthouse, 45 Fed. Reg. 26,046 (1980) [hereinafter cited as Final EPA Race Regulations]; Federal Trade Commission, Trade Regulation Rulemaking Procedures, 44 Fed. Reg. 36,171 (1979). Race-to-the-courthouse designations in two individual agency rules have been upheld by the courts of appeals. Virginia Elec. \& Power Co. v. EPA, 610 F.2d 187 (4th Cir. 1979); Southland Mower Co. v. CPSC, 600 F.2d 12 (5th Cir. 1979). Other race-to-the-courthouse regulations were recently promulgated by OSHA. 29 C.F.R. $\$ \$ 1911.12(a)(2)$, 1911.18(d) (1980).

18 See Westinghouse Elec. Corp. v. NRC, 598 F.2d 759, 767 (3d Cir. 1979). See also Virginia Elec. \& Power Co. v. EPA, 610 F.2d 187, 189 n.5 (4th Cir. 1979); United Steelworkers v. Marshall, 592 F.2d 693, 695 (3d Cir. 1979); American Pub. Gas Ass'n v. FPC, 555 F.2d 852, 857 (D.C. Cir. 1976).

19 See, e.g., Tenneco Oil Co., Additional Findings of Fact, Pursuant to Court Order, Concerning Filings of Petitions for Review of FERC Opinion Nos. 10 and 10-A, FERC Docket Nos. CI75-45 et al. (Sept. 20, 1979); Leventhal, A Modest Proposal for a Multi-Circuit Court of Appeals, 24 AM. U. L. Rev. 881, 909 (1975) (describing the race-to-the-courthouse factfinding process used in Environmental Defense Fund, Inc. v. EPA, 510 F.2d 1292 (D.C. Cir. 1975)). 


\section{Forum Shopping-An Analysis of the Problem}

\section{A. Varieties of Forum Shopping}

The recent history of appeals from the Occupational Safety and Health Administration's (OSHA) standards for toxic chemicals provides an excellent example of forum shopping in operation. After OSHA's early standards for fourteen carcinogens, ${ }^{20}$ asbestos, ${ }^{21}$ and vinyl chloride ${ }^{22}$ had been affirmed in all major respects by the Third, District of Columbia, and Second Circuits, respectively, lawyers for the petroleum industry sought to have OSHA's emergency temporary standard for benzene reviewed in the Fifth Circuit..23 The affected union sought review in the District of Columbia Circuit. ${ }^{24}$ The race to the courthouse, however, was complicated by the lack of a definitive starting gun. Agency officials met with industry and union officials between 9:30 and 10:00 a.m. on April 29, 1977 to announce the agency's decision. Immediately after this meeting the union petitioners filed a petition in the District of Columbia Circuit. Notice of the agency decision was not published in the Federal Register until May 3, 1977, and the industry petitioners filed their petition for review in the Fifth Circuit on May 10, 1977. The Fifth Circuit transferred the proceedings to the District of Columbia Circuit for a determination as to the appropriate circuit for a decision on the merits. In Industrial Union Department $v$. Bingham, ${ }^{25}$ the District of Columbia Circuit panel split three ways on this threshold question.

Judge Fahy agreed with the agency that the regulations became effective at the end of the April 29 meeting. ${ }^{26}$ Because the

${ }^{20}$ Synthetic Organic Chem. Mfrs. Ass'n v. Brennan, 506 F.2d 385 (3d Cir. 1974), cert. denied, 423 U.S. 830 (1975); Synthetic Organic Chem. Mfrs. Ass'n v. Brennan, 503 F.2d 1155 (3d Cir. 1974), cert. denied, 420 U.S. 973 (1975).

21 Industrial Union Dep't v. Hodgson, 499 F.2d 467 (D.C. Cir. 1974).

22 Society of Plastics Indus., Inc. v. OSHA, 509 F.2d 1301 (2d Cir.), cert. denied, 421 U.S. 992 (1975).

${ }^{23}$ See Industrial Union Dep't v. Bingham, 570 F.2d 965 (D.C. Cir. 1977). It is not clear why the industry petitioners chose the Fifth Circuit, rather than any one of the other six available circuits. Because much of the petroleum industry is located in Fifth Circuit states, convenience may have been a factor. However, this does not explain why the American Petroleum Institute, a Washington, D.C.based organization, would choose the Fifth Circuit; nor does it explain why Washington, D.C. counsel, who briefed and argued the case, would choose that circuit. More likely, that circuit's general pro-industry reputation, see note 42 infra, and its recent opinion in a case involving a related issue under a different statute, see Aqua Slide 'N' Dive Corp. v. CPSC, 569 F.2d 831 (5th Cir. 1978), guided counsel in a southerly direction.

24 See Industrial Union Dep't v. Bingham, 570 F.2d 965 (D.C. Cir. 1977).

25570 F.2d 965 (D.C. Cir. 1977) (per curiam).

26 Id. 976-79 (Fahy, J., dissenting). 
union was the first to file after that meeting, venue was proper in the District of Columbia Circuit unless the convenience of the parties or justice demanded transfer to the Fifth Circuit. Judge Fahy felt that the District of Columbia Circuit was most convenient to the parties and therefore saw no reason to transfer. ${ }^{27}$

Judge Leventhal agreed with Judge Fahy that the petition was first filed for the purposes of section 2112(a) in the District of Columbia Circuit and that it was the most convenient, pointing out that the parties all had counsel and other representatives in Washington, D.C. ${ }^{28}$ Nevertheless, Judge Leventhal believed that "the interest of justice" required that the court transfer the case to the Fifth Circuit. Because the record disclosed that not all of the parties to the administrative proceedings were invited to the informal meeting of April 29, 1977, at least some parties were deprived of the opportunity to enter the race. To avoid the appearance of unfairness, Judge Leventhal voted to transfer. ${ }^{29}$

Judge Wilkey agreed with the industrial petitioners that the District of Columbia Circuit did not even have jurisdiction, because the union filed its petition prior to the time that the agency issued its order..$^{30}$ Judge Wilkey believed that the agency order had not been issued until it had been made available to the general public, which was subsequent to the filing of the union's petition. ${ }^{31}$ The union's petition was therefore invalid, and the case belonged to the Fifth Circuit, where the only valid petitions had been filed. In order to avoid a complete impasse, however, Judge Wilkey speculated that had jurisdiction been proper in the District of Columbia Circuit he would have voted to transfer to the Fifth Circuit in accordance with Judge Leventhal's reasoning. ${ }^{32}$ The case was therefore transferred.

The Industrial Union case might easily have had little practical impact, beyond providing an entertaining diversion for civil procedure dilettantes, had the Fifth Circuit simply followed existing precedents. That court, however, interpreted the agency's statute

27 Id. 979-81. Judge Fahy concluded that the "interest of justice" language in 28 U.S.C. $\$ 2112(\mathrm{a})$ (1976) simply elaborated upon the "convenience of the parties," and did not give the court independent grounds for transferring a case. Id. 979. See note 150 infra.

28570 F.2d at $967-71$ (opinion of Leventhal, J.).

29 Id. 972.

30 Id. 973-76 (opinion of Wilkey, J.).

31 Judge Wilkey would have the race begin when "all affected parties have equal opportumity to gain actual knowledge of the agency action." Id. 976 (emphasis omitted).

32 Id. 967 (per curiam). 
differently from the District of Columbia, Second, and Third Circuits, and it remanded to the agency for further proceedings. ${ }^{33}$ The Supreme Court agreed to resolve the conflict in the circuits, and ultimately upheld the Fifth Circuit's remand..$^{34}$ In the meantime, given the split in circuits, the race to the courthouse for review of OSHA toxic substance standards assumed a much greater significance.

OSHA's next standard, setting maximum workplace exposure levels for lead, predictably precipitated a frantic race to the Third and Fifth Gircuits that ended in a dead heat. ${ }^{35}$ The two courts conferred informally and decided that the Third Circuit should determine which court should hear the case on the merits. ${ }^{36}$ Pointing out that " $[\mathrm{u}]$ nlike race tracks, . . . courts are not equipped with photoelectric timers," 37 the court refused to decide which party actually filed first. After declining to use several other suggested transfer criteria and finding that neither party would be inconvenienced by review in either circuit, the court tossed the lighted squib to the District of Columbia Circuit. The court reasoned that because the District of Columbia Circuit would soon decide many of the same questions concerning the health effects of lead in the recently filed appeal from the Environmental Protection Agency's (EPA) ambient air quality standard for that element, that circuit was the logical court to take the lead. ${ }^{38}$ The court recognized that no one had filed a petition for review in the District of Columbia Circuit, but insisted that this should not be determinative because most counsel were located in the District of Columbia in

${ }^{33}$ American Petroleum Inst. v. OSHA, 581 F.2d 493 (5th Cir. 1978), aff'd sub nom. Industrial Union Dep't v. American Petroleum Inst, 100 S. Ct. 2844 (1980).

The race chronicled here was theoretically for review only of OSHA's temporary emergency standard for benzene. The court as a practical matter eliminated that standard when on May 20,1977, it issued a stay of that standard pending appeal. Because there was never a hearing on appeal, the stay was never lifted and the emergency temporary standard never went into effect. See Occupational Exposure to Benzene, 43 Fed. Reg. 5918, 5919 (1978). Petitions for review of the final benzene standard were filed in several circuits, but they were all transferred to the Fifth Circuit. American Petroleum Inst. v. OSHA, 581 F.2d at 500. The reasons for the transfer of these appeals were not published, but one can surmise that the Fifth Circuit's retention of jurisdiction over the appeal from the emergency temporary standard was an important factor. See text accompanying notes 137-49 infra.

34 Industrial Union Dep't v. American Petroleum Inst., 100 S. Ct. 2844 (1980). 35 United Steelworkers v. Marshall, 592 F.2d 693, 695 (3d Cir. 1979).

36 Id.

$37 \mathrm{Id}$.

38 Id. 697-98. The court might also have mentioned that the District of Columbia Circuit had gained some familiarity with lead-related issues in Ethyl Corp. v. EPA, 541 F.2d 1 (D.C. Cir.), cert. denied, 426 U.S. 941 (1976). 
any event. ${ }^{39}$ The parties' race thus left them at a somewhat unexpected finish line.

The foregoing example demonstrates that forum shopping comes in several varieties and can occur at several stages in the evolution of an administrative program. When the agency first issues an order, sets a national standard, or promulgates national regulations, there will generally be no controlling precedent in the circuit courts. An attorney for an aggrieved party can therefore choose from among the circuits where venue is proper. ${ }^{40}$ The attorney may choose one circuit over another for a number of reasons, including the convenience of the lawyer, the convenience of the client, the inconvenience of the opponent, the status of the courts' dockets, or the attorney's perception that his or her client is more likely to prevail in one circuit than in another. ${ }^{41}$ If, for example, the attorney plans to argue that the record support for the agency's decision is inadequate under the "arbitrary and capricious" or "substantial evidence" standards, the attorney might file the appeal in a circuit that he or she perceives to be less deferential torvard administrative factfinding. Alternatively, the attorney might choose a circuit for its reported philosophical bent. ${ }^{42} \mathrm{Fi}$ -

39592 F.2d at 698.

40 The attorney must look to the venue provisions of the agency's statute to ascertain the forums in which venue is proper. Usually, the statutes provide for venue in the District of Columbia Circuit or the circuit in which the aggrieved party resides or is conducting business. See 15 Wright \& MILLER, supra note 4, at $\$ 3816$. Occasionally, venue is proper exclusively in the District of Columbia Circuit.

If the applicable venue statute is sufficiently vague, a loser of a first-to-file race can sometimes preempt the application of $\$ 2112(\mathrm{a})$ by arguing that venue is "inappropriate" in the first-filed circuit. See, e.g., Dayton Power \& Light Co. v. EPA, 520 F.2d 703 (6th Cir. 1975).

41 See generally Commission on Revision of the Federal Court Appellate System, Structure and Internal Procedures: Recommendations for Change, 67 F.R.D. 195, 382-90 (1975) [hereinafter cited as Hruska Commission Report].

42 In Industrial Union Dep't v. Bingham, 570 F.2d 965 (D.C. Cir. 1977), for example, the union probably selected the District of Columbia Circuit because that circuit reputedly placed human health concerns on a higher footing than economic considerations. See Environmental Defense Fund, Inc. v. Ruckelshaus, 439 F.2d 584, 598 (D.C. Cir. 1971).

Over sufficient periods of time, the courts of appeals acquire reputations among practicing attorneys that guide them either toward or away from particular circuits in particular kinds of cases. For example, rumor has it that on environmental questions the District of Columbia Circuit and First Circuit generally tend to favor the agency, while the Fourth and Fifth Circuits are generally more "pro-business." See Klement, Agencies Look for Trigger to Courthouse Race, Nat'l L.J., Aug. 6, 1979, at 7, col. 1; Ross \& Goldman, Racing to the Court: An "Unseemly" Way to Challenge Agency Orders, Nat'l L.J., March 3, 1980, at 27, col. 1; cf. DeLong, Informal Rulemaking and the Integration of Law and Policy, 65 VA. L. REv. 257, 281 n.126 (1979) (comparing District of Columbia and Fifth Circuits). The reading of the circuits' predilections, of course, depends heavily on the nature of the action being reviewed. For many agencies, the District of Columbia Circuit 
nally, if the client is a major industry that is concentrated in a particular geographical area, the lawyer might shop for the circuit encompassing that area because of his or her perception that the court will be more favorably inclined toward the local client.

After one court has ruled on a question of law or fact involving a given administrative program, lawyers in future litigation involving the same program will have a greater incentive to forum shop. ${ }^{43}$ The lawyer who now has a favorable precedent in one circuit will of course attempt to have his or her appeal heard in that circuit. The incentive will be especially strong if the previous court ruled for or against the agency on a question of statutory interpretation or procedural implementation, because the former court can be expected to follow the "law of the circuit" and reaffirm its prior holding. ${ }^{44}$ The incentive should be somewhat weaker if the prior decision simply tested the record support for an agency's factual premises and inferences under the "substantial evidence" or "arbitrary and capricious" tests. A prior holding that

appears to be the least likely circuit to uphold agency action. See, e.g., Hruska Commission Report, supra note 41, at 383-84, 387 (statements of general counsels of Comptroller of the Currency and General Service Administration). Finally, a court's approach to a particular agency action may depend more upon the court's philosophical view as to the merits of the action than upon its legal approach to judicial review of administrative action, and courts acquire reputations for philosophical outlooks as well as for deference to agency action or lack thereof.

Whether or not judicial performance warrants these general perceptions is not directly relevant. See generally Lang \& Thomas, Disposition of Patent Cases by Courts During the Period 1939-1949, 32 J. PAT. OFF. Soc'x 803 (1950) (tabulating patent cases by circuit); Comment, Forum-Shopping in the Review of NLRB Orders, 28 U. CHr. L. REv. 552 (1961); Comment, Forum-Shopping in Appellate Review of FTC Cease and Desist Orders, 1968 UTAF L. REv. 316. The incentive to forum shop is based upon perceptions, not reality. This author has collected sufficient evidence to suggest that attorneys do in fact forum shop on the basis of their perceptions of the general tendencies of the various circuits. He sent a letter to 62 attorneys who were listed as attorneys of record in cases involving races to the courthouse or involving large national environmental and energy cases in which forum shopping was possible. Confidentiality was assured the recipients. Of the 18 relevant responses, 17 stated that in choosing a forum for review they relied upon their perceptions that their clients' interests were more likely to prevail in the forums of their choice. Fifteen called this the most significant factor in their choice. Only seven stated that they considered either their convenience or the convenience of their clients in choosing from among the circuits, and seven stated categorically that convenience was not a consideration. Notes on file with author.

43 In one, perhaps extreme, example a petitioner established a place of business in the Seventh Circuit solely to take advantage of a favorable prior precedent. Gerson v. FTC, 325 F.2d 93, 94 n.2 (7th Cir. 1963).

${ }^{44}$ See Friendly, The "Law of the Circuit" and All That, 46 St. JoHn's L. Rev. 406 (1972); Vestal, Relitigation by Federal Agencies: Conflicts, Concurrence and Synthesis of Judicial Policies, 55 U.N.C. L. REv. 123, 161 (1977). The attorney, of course, cannot have absolute assurance that the panel of the circuit court that he or she draws will follow the holding of the former panel. See generally Wasby, Inconsistency in the United States Courts of Appeals: Dimensions and Mechanisms for Resolution, 32 VAND. L. REv. 1343 (1979). 
an agency's decision either has or lacks sufficient record support is not a particularly strong indicator of how another panel of the circuit will view the record support for a different decision by the same agency. Yet the language of the court's opinion may give some indication of the degree to which the court is willing to demand that the agency explain itself. This, in addition to the general reputation of the courts discussed earlier, ${ }^{45}$ may provide sufficient incentive to choose one court over another.

The attorney in a later case representing a client who disagrees with the first appellate court's holding will have a similar incentive to avoid the former forum; this type of forum shopping might more appropriately be labeled "forum avoidance." Although intercircuit disputes on questions of law are not uncommon, ${ }^{46}$ prior precedents in one circuit are likely to be followed in other circuits, ${ }^{47}$ and the attorneys in later cases will thus have less incentive to forum shop than their predecessors had. Nevertheless, as the American Petroleum Institute learned in the benzene case, ${ }^{48}$ the potential rewards may justify the extra expense, even if the chances for victory are low. When the prior court only examined the record support of the agency's conclusions, however, the incentive to avoid that circuit may not be as high, especially if the former holding runs contrary to the court's general reputation.

\section{B. The Policies For and Against Forum Shopping}

\section{Disadvantages of Forum Shopping}

\section{a. Public Image of Lawyers and Courts}

The spectacle of a race to the courthouse may detract somewhat from the public image of the judicial system as an impartial and consistent dispenser of justice. Hence, blatant attempts to select forums are often condemned as "unseemly." 49 Yet, because races

45 See note 42 supra.

${ }^{46}$ See Vestal, supra note 44 , at 162.

47 See id. 165-66.

48 American Petroleum Inst. v. OSHA, 581 F.2d 493 (5th Cir. 1978), aff'd sub nom. Industrial Union Dep't v. American Petroleum Inst., 100 S. Ct. 2844 (1980).

49 See, e.g., Wearly v. FTC, 616 F.2d 662, 664 n.I (3d Cir. 1980); Industrial Union Dep't v. Bingham, 570 F.2d 965, 970 (D.C. Cir. 1977) (opinion of Leventhal, J.); Rayco Mfg. Co. v. Chicopee Mfg. Corp., 148 F. Supp. 588, 592-93 (S.D.N.Y. 1957); Leventhal, supra note 19, at 909 ("Discussion often castigates 'unseemly' forum shopping, although I have never seen a reference to 'seemly' forum shopping."); Ross \& Goldman, supra note 42, at 27; Vestal, supra note 44, at 165 . 
to the courthouse and other more subtle attempts to forum shop rarely claim much, if any, media attention outside of the specialized legal press, this fear may be somewhat overblown.

\section{b. Judicial Comity}

When two courts are presented with the opportunity to review the same administrative order, judicial comity demands that one court yield to the other. ${ }^{50}$ The doctrine of judicial comity is thus designed to prevent "unseemly conflict" among the courts. ${ }^{51}$ But the doctrine does not always specify which court shall yield. Forum shopping attempts can therefore threaten the carefully nurtured goodwill that exists among the federal appellate courts. An extreme example of a threat to judicial comity caused by forum shopping is Montship Lines, Ltd. v. FMB, ${ }^{52}$ in which petitions for review of a Federal Maritime Board order were filed in the Second and District of Columbia Circuits. The first petition was filed in the District of Columbia Circuit, and the agency filed a certified appendix of the record in that circuit. Nevertheless, the Second Circuit upheld the order before the District of Columbia Circuit had ruled on the matter.53 The District of Columbia Circuit, taking note of the Second Circuit decision, assumed jurisdiction and vacated the order. The court did not explain why the Second Circuit holding was not res judicata; it held only that the question of the Second Circuit's jurisdiction was not before it. ${ }^{54}$

For obvious reasons the courts of appeals would prefer that they not be forced into the position of issuing orders that directly conflict with those of sister courts or that effectively govern proceedings in other circuits. Because federal agencies often take actions that are appropriate for review in more than one circuit, forum shopping for review of administrative action can be a particularly potent threat to judicial comity. ${ }^{55}$ With a few exceptions,

50 See, e.g., Kerotest Mfg. Co. v. C-O-Two Fire Equip. Co., 342 U.S. 180, 183 (1952). See also GTE Sylvania, Inc. v. Consumers Union of United States, Inc., 100 S. Ct. 1194, 1202 n.11 (1980).

51 Valley Vision, Inc. v. FCC, 383 F.2d 218, 219 (D.C. Cir. I967).

E2 295 F.2d 147 (D.C. Cir. 1961).

53 Kerr S.S. Co. v. United States, 284 F.2d 61 (2d Cir. 1960), vacated as moot, 369 U.S. 422 (1962).

54295 F.2d at 151. See also Environmental Defense Fund, Inc. v. EPA, 485 F.2d 780 (D.C. Cir. 1973) (District of Columbia Circuit orders parties to proceedings in Northern District of Mississippi to move for immediate dismissal in that court so that proceedings may be heard in their entirety in the District of Columbia Circuit).

65 See, e.g., Consumers Union of United States, Inc. v. CPSC, 590 F.2d 1209 (D.C. Cir. 1978) (even though District of Delaware enjoined agency from releas- 
such as the case discussed above, however, the federal first-to-file statute ${ }^{56}$ has avoided threats to judicial comity, because it specifies precisely which court shall take jurisdiction. Yet, the recent wave of cases involving simultaneous filings ${ }^{57}$ has renewed the threat to judicial comity. Thus far, courts of appeals have been able to work out privately the court that decides which court shall hear the merits of controversies involving simultaneous filings. ${ }^{58}$ That informal approach may become increasingly strained in the future as simultaneous filings begin to occur in more than two circuits.59

\section{c. Uniform Application of Agency Policy}

Forum shopping can threaten agency attempts to apply policy uniformly across the country. ${ }^{60}$ The most immediate impact of forum shopping on an agency's decisionmaking process is the effect on the agency of the knowledge that its action may well be reviewed by the least sympathetic of all of the federal courts. For administrative factfinding and inference-drawing this effect may be altogether salutary. Careful agency analysis is generally a thing to be encouraged, and the courts of appeals are in any event usually disinclined to substitute their judgments for that of the agency on questions of factual inference. For questions involving statutory interpretation and the implementation of broad statutory policies, however, the knowledge that an unsympathetic court might inter-

ing data, District of Columbia district court could order agency to release the same data), rev'd sub nom. GTE Sylvania, Inc. v. Consumers Union of United States, Inc., 100 S. Ct. 1194 (1980).

5628 U.S.C. $\$ 2112(\mathrm{a})$ (1976).

57 See cases cited in note 206 infra.

58 See text accompanying notes 209-10 infra.

59 The conflict predicted has in fact recently arisen in the context of a jurisdictional squabble between the Fourth and District of Columbia Circuits. Petitions for review of certain EPA regulations were filed simultaneously in the Fourth, Fifth, and District of Columbia Circuits. Faced with the task of deciding which circuit would hear the petitions, the three circuits conferred informally and decided to settle the question by lot. The Fourth Circuit was chosen. See National Resources Defense Council, Inc. v. EPA, 15 ENvIR. ReP. (BNA) 1157 (D.C. Cir. 1980). The District of Columbia Circuit, however, apparently refused to be bound by the results of the lottery and broke off negotiations. See Virginia Elec. \& Power Co. v. EPA, Nos. 79-1347 et al. (4th Cir. Oct. 16, 1980) (unpublished order). Miffed, the Fourth Circuit went ahead and assumed jurisdiction. See id. The District of Columbia Circuit nonetheless ignored the Fourth Circuit order cited supra, assumed jurisdiction, and in a lengthy opinion issued in November, 1980, explained why it and not the Fourth Circuit should hear the case. See National Resources Defense Council, Inc., I5 ENvir. Rep. at 1157-64. Thus, the matter is being adjudicated before two circuits, each refusing to give way to the other.

60 See, e.g., Dayton Power \& Light Co. v. EPA, 520 F.2d 703, 708 (6th Cir. 1975); Natural Resources Defense Council, Inc. v. EPA, 465 F.2d 492, 495 (Ist Cir. 1972). See also Currie \& Goodman, supra note 3, at 65-66. 
pret its statute differently may cause the agency to be unduly timid in implementing its statutory mandate. ${ }^{\mathbf{1 1}}$

Even if an agency chooses to implement forcefully its mandate and risk a legal challenge in a potentially unfriendly circuit, a successful defense before the court does little to ensure the evolution of a uniform policy. Other parties in later litigation can race to different circuits to obtain conflicting interpretations. In this age of the "polycentric" administrative dispute, ${ }^{62}$ the ability to forum shop may leave the law unsettled until the Supreme Court decides the issue, which in many cases can be a substantial length of time. Particularly when the agency is facing statutorily imposed deadlines, this uncertainty can defeat the successful implementation of national policy. ${ }^{63}$ The OSHA experience is once again a good example. After OSHA's approach to regulating toxic chemicals in the workplace had survived appeals in three circuits, ${ }^{64}$ the agency sought to solidify some of the principles that had been announced in those cases in a generic carcinogen regulation. OSHA anticipated that the generic regulations would eliminate the need to litigate certain questions, such as the validity of extrapolating from laboratory animals to humans, ${ }^{65}$ on a case-by-case basis. In the midst of the rulemaking proceeding on the generic regulations, however, the Fifth Circuit, following a classic race to the courthouse, ruled that OSHA's former approach did not comply with the statute. ${ }^{66}$ This holding, of course, cast a pall upon the generic carcinogen effort, and the new issues raised by the Fifth Circuit litigation slowed down the rulemaking process considerably.

Fortunately, the Supreme Court has been diligent in detecting conflicts among the circuits on questions of statutory interpretation involving nationally applicable administrative standards, and it has

61 The author recalls many instances during his stint with the Environmental Protection Agency, Office of General Counsel, in the mid-1970s in which agency lawyers evaluated a regulation to determine whether it would survive review in the Fourth Circuit, the court perceived to be the most hostile forum for review of EPA regulations.

62 See Boyer, Alternatives to Administrative Trial-Type Hearings for Resolving Complex Scientific, Economic, and Social Issues, 71 Mrch. L. Rev. 111, 116-20 (1972).

63 See Pan Am. World Airways, Inc. v. CAB, 517 F.2d 734, 741 (2d Cir. 1975); Hruska Commission Report, supra note 41, at 382-87.

64 See notes 20-22 supra \& accompanying text.

65 The Third Circuit had opined that the mouse-to-man extrapolation problem was "a legal rather than a factual determination." Synthetic Organic Chem. Mfrs. Ass'n v. Brennan, 503 F.2d 1155, 1159 (3d Cir. 1974), cert. denied, 420 U.S. 973 (1975).

66 American Petroleum Inst. v. OSHA, 581 F.2d 493 (5th Cir. 1978), affd sub nom. Industrial Union Dep't v. American Petroleum Inst., 100 S. Ct. 2844 (1980). 
granted certiorari in most of the important recent cases. ${ }^{67}$ If the Court continues this practice, agencies and litigants will at least have some assurance that administrative programs will not remain in flux indefinitely. Even this, however, may not be enough when the agency is operating under a statutory deadline. For example, although the District of Columbia Circuit in 1975 strongly intimated that EPA had authority to promulgate uniform national effluent limitations for categories of existing industrial sources mandating the application of the best practicable technology economically achievable by July 1, 1977, ${ }^{\text {ss }}$ the Eighth Gircuit held that EPA had no such authority. ${ }^{69}$ EPA nevertheless adhered to its original position and received favorable rulings on this point from six other circuits $^{70}$ before the Supreme Court finally granted certiorari in one of the cases and ruled in EPA's favor. ${ }^{71}$ It was thus not until February 23, 1977-five months before the technology was to be in place-that EPA's authority was definitively established. Because EPA had not always insisted during the pendancy of the litigation that its uniform guidelines be incorporated into industrial-waste discharge permits, it was impossible for many of the sources to comply with the 1977 deadline. ${ }^{72}$ Congress ultimately amended the Act to give those companies that had been litigating

67 See, e.g., Industrial Union Dep't v. American Petroleum Inst., $100 \mathrm{~S}$. Ct. 2844 (1980); United States v. Ward, 100 S. Ct. 2636 (1980); E.I. du Pont de Nemours \& Co. v. Train, 430 U.S. 112 (1977); Union Elec. Co. v. EPA, 427 U.S. 246 (1976); Train v. Natural Resources Defense Council, Inc., 421 U.S. 60 (1975). 1975).

68 Natural Resources Defense Council, Inc. v. Train, 510 F.2d 692 (D.C. Cir.

69 CPC Int'l v. Train, 515 F.2d 1032 (8th Cir. 1975).

70 American Petroleum Inst. v. EPA, 540 F.2d 1023 (10th Cir. 1976), cert. denied, 430 U.S. 922 (1977); American Frozen Food Inst. v. Train, 539 F.2d 107 (D.C. Cir. 1976); Hooker Chem. \& Plastics Corp. v. Train, 537 F.2d 620 (2d Cir. 1976); E.I. du Pont de Nemours \& Co. v. Train, 541 F.2d 1018 (4th Cir. 1976), aff'd in relevant part, 430 U.S. 112 (1977); American Meat Inst. v. EPA, 526 F.2d 442 (7th Cir. 1975); American Iron \& Steel Inst. v. EPA, 526 F.2d 1027 (3d Cir. 1975).

71 E.I. du Pont de Nemours \& Co. v. Train, 430 U.S. 112 (1977).

72 During this time, EPA and the states that had permit-writing authority had been issuing permits pursuant to 33 U.S.C. $\$ 1342$ (a)(1) (1976), which allowed the permitting authority, prior to implementation of the national effluent limitations, to apply "such conditions as the Administrator determines are necessary to carry" out the provisions of this Act." See W. RODGERS, ENVIRONMENTAL Law $\$ 4.11$ (1977). Each permitting action, however, could be appealed to the Administrator for an adjudicatory hearing, and ultimately for review in a court of appeals, see Marathon Oil Co. v. EPA, 564 F.2d 1253 (9th Cir. 1977); United States Steel Corp. v. Train, 556 F.2d 822 (7th Cir. 1977), where the technological questions that were settled in the litigation over the national standards could be relitigated on a case-by-case basis. Not surprisingly, many of the permits issued during the interim period were not as stringent as the national effluent limitations would have required. See La Pierre, Technology-Forcing and Federal Environmental Protection Statutes, 62 Iowa L. Rev. 771, 822 (1977). 
this issue with EPA until April, 1979 to comply with the national effluent limitations. ${ }^{73}$

\section{d. Business Uncertainty}

Forum shopping for review of questions of law can produce an environment of uncertainty that may discourage businesses from investing capital in productive enterprises. ${ }^{74}$ Once a court of appeals has decided a nationally applicable question of law, individual companies affected by that ruling understandably would like to rely on the holding in making future business decisions. They cannot confidently prepare for the future, however, if there is a strong possibility that the agency, a competitor, union, or public interest group might obtain a contrary ruling from another court of appeals sometime in the future. For important questions of national energy, environmental and health policy, and, to a more limited extent, labor policy, the uncertainty generated by the possibility of future inconsistent holdings might have detrimental consequences for investment on a national scale.

The effects of forum shopping on business uncertainty should not, however, be exaggerated. The amount of additional uncertainty due to the possibility that courts of appeals will reach inconsistent decisions on questions of law may not be great when compared to the uncertainty due to other business imponderables. ${ }^{75}$ Indeed, a business always faces the risk, entirely unrelated to forum shopping, that Congress will reverse a court of appeals ruling by amending the agency's statute. In volatile regulatory areas, such as energy and environmental regulation, this risk is easily as great as the risk of conflicting appellate decisions. Finally, such business

73 Clean Water Act $\$ 309$ (a)(5)(B), Pub. L. No. 95-217, $\$ 56(c)$, 91 Stat. 1593 (1977) (codified at 33 U.S.C. $\$ 1319$ (a)(5)(B) (Supp. III 1979)). See Monongahela Power Co. v. EPA, 586 F.2d 318 (4th Cir. 1978). Similar delay in securing judicial review of EPA's recently promulgated rules for implementing the National Pollution Discharge Elimination System permit-granting process threatens successful implementation of that program. See Sive, EPA Water Pollution Rules: Stuck In a Multiple Review Bottleneck, Nat'l L.J., March 10, 1980, at 25, col. 1. A similar fate may await OSHA's new carcinogen rules. See [1980] 3 CrieM. Reg. Rep. (BNA) 1874.

74 See Carrington, Crowded Dockets and the Courts of Appeals: The Threat to the Function of Review and the National Law, 82 Hanv. L. Rev. 542, 597 (1969) ("To the extent that circuits seem to offer the planner different results, ventures that are only marginal on an economic assessment are overlaid with unresolvable confusion."); Leventhal, supra note 19, at 896; Pierce, The Choice Between Adjudicating and Rulemaking for Formulating and Implementing Energy Policy, 31 Hastings L.J. 1, 21-27 (1979) (detailing the costs to society of business uncertainty due to delay in resolving crucial national energy issues).

75 See H. Ratffa, Dectsion Anatysis: Introductory Lectures on Choices UNDER UNCERTANTTY 27-32 (1968). 
risks are most likely to result from forum shopping to secure review of questions of law. Given the greater degree of deference accorded by the appellate courts to agency findings of fact, the chance of significant differences in appellate review of administrative factual determinations is relatively remote.

\section{e. Costs of Forum Shopping}

Forum shopping costs money. Under the current first-to-file statute, parties spend much time and money on the walkie-talkies and other arcane paraphernalia necessary to pursue their elaborate races to the courthouse. Once the race is complete the parties frequently consume additional resources litigating over who won the race. In the case of simultaneous filings, and in any alternative system that relies upon a balancing of criteria to determine the appropriate circuit, the parties must consume further time and energy debating the correct balance of the relevant factors. One can justifiably question the fairness and efficacy of a system that demands costly expenditures for the rendering of threshold determinations, irrelevant to the merits of the case, especially in situations in which one party can ill-afford the cost. ${ }^{76}$ In addition to the drain on client resources, forum shopping consumes the judicial and agency resources that must go into administering the forum shopping mechanism. Finally, forum shopping on questions of law can result in two or more courts devoting valuable judicial resources to duplicative efforts. ${ }^{77}$

\section{The Advantages of Forum Shopping}

Despite its numerous costs, forum shopping has two offsetting advantages. For questions of law and for some generally applicable questions of procedure, forum shopping can provide the Supreme Court with the opportunity to observe how several circuit court judges have resolved difficult questions before deciding them for itself. For example, the Supreme Court in deciding that EPA had authority to set national effluent limitations under the Clean Water Act ${ }^{78}$ noted "the wisdom of allowing difficult issues to ma-

76 See note 114 infra \& accompanying text.

77 See Natural Resources Defense Council, Inc. v. EPA, 465 F.2d 492, 495 (1st Cir. 1972) ("[W]e do not feel that judicial manpower is so abundant so [sic] as to permit several circuits to solve identical complex legal and factual issues . . . .").

78 See text accompanying notes 68-73 supra. 
ture through full consideration by the courts of appeals." 79 Similarly Judge Leventhal has suggested that " $t]$ here are advantages of multiple judicial input on issues. This is a concept of feedback, of a simmering or percolating effect." 80 Other commentators have likewise stressed the value of creative conflicts among the circuits. $^{81}$ Additionally, the conflict in the circuits that can result from forum shopping can be a very effective signal to the Supreme Court that an important issue needs its attention. ${ }^{82}$ Forum shopping on legal and perhaps procedural questions can thus benefit the legal process. The extent to which the "percolation" and signaling advantages of forum shopping outweigh its significant disadvantages is an overriding question to be addressed in connection with the following critical analysis of the current first-to-file rule and the possible alternatives for reform.

\section{Current Practice Under Section 2112 (a)}

Before 1958, an agency's ability to file the record in a court of appeals gave it the practical power to choose which of the available circuits would hear the appeal. ${ }^{83}$ In 1955, however, the Com-

79 E.I. du Pont de Nemours \& Co. v. Train, 430 U.S. 112, 135 n.26 (1977). See also Circuit Clash Heartens EPA Air Enforcers, Legal Times of Washington, Aug. 20, 1979, at 17, col. 1 .

80 Leventhal, supra note 19, at 908 (footnote omitted).

81 See H. Friendly, Federat Jurisdiction: A General View 186 (1973) [hereinafter cited as GENERAL Vnew]; Currie \& Goodman, supra note 3, at 69; Hruslia Commission Report, supra note 41, at 219; Oakes, Developmenis in Environmental Law, [1973] 3 ENvT'L L. REP. (ELI) 50,001, 50,011. But see Note, Securing Uniformity in National Law: A Proposal for National Stare Decisis in the Courts of Appeals, 87 YaLE L.J. 1219, 1245 (1978) ("It is not at all clear, however, that conflict consistently produces such synthesis. In regulatory law-much concerned, as it is, with detail-conflict is likely to create confusion among lawyers, clients, and the judiciary.").

82 So long as the Supreme Court is relied on to be the final arbiter of the interpretation of regulatory statutes, conflicts are a good thing-not a bad one. They point up the areas where there are grounds for reasonable differences of opinion and flash a signal to which the Court must ultimately respond.

Remarks by Henry Friendly, Appellate Judges' Conference, A.B.A. Convention (Aug. 4, 1968), reprinted in CASE \& Comment, March-April, 1969, at 23, 25. See also GENERAL VIEW, supra note 81, at 187. These advantages of forum shopping are less obvious in cases in which the only issue is the sufficiency of the record support for the agency's factual determinations. Differing appellate court holdings on diverse factual determinations can have little educational value for the Supreme Court; nor can they effectively signal the need for Supreme Court review of agency factinding and inference-drawing.

83 See Ball v. NLRB, 299 F.2d 683, 687 (4th Cir.), cert. denied, 369 U.S. 838 (1962) (detailing the legislative history of 28 U.S.C. $\$ 2112$ (a) (1976)); 16 WrugerT \& MriLer, supra note 4, \$3944, at 332; Comment, A Proposal to End the Race to the Court House in Appeals from Federal Administrative Orders, 68 Colum. L. Rev. 166, 168-69 (1968). 
mittee of Revision of the Latws of the Judicial Conference of the United States proposed to limit the agency's discretion by requiring that the record be filed in the circuit "in which in its judgment the proceedings may be carried on with the greatest convenience to all the parties involved." ${ }^{84}$ After the American Bar Association and several agencies complained that this would still give agencies too much discretion, ${ }^{85}$ Congress enacted section 2112 (a), ${ }^{86}$ which provides that the record shall be filed in the circuit in which the first petition was filed. That circuit may in turn transfer the proceedings to any other court of appeals "[f]or the convenience of the parties in the interest of justice." 87 The courts of appeals have, in addition, recognized an "inherent power" in a court of appeals to transfer a case to another court of appeals irrespective of any statutory authority. ${ }^{88}$ In the typical case, however, the circuit in which the first petition is filed will hear the merits of the appeal, ${ }^{89}$ a prospect that has precipitated vigorous and wasteful races to the courthouse. ${ }^{90}$

One of the most bizarre and expensive courthouse races occurred in an appeal from a recent Federal Energy Regulatory Commission (FERC) decision, Tenneco Oil Company. ${ }^{91}$ On June 21, 1978 FERC issued an opinion denying applications for rehear-

84 H.R. 6682, 84th Cong., 1st Sess. $\$ 2$ (1955), reprinted in Appeal of Administrative Agency Decisions: Hearings on H.R. 6682 Before Subcomm. No. 3 of the House Comm. on the Judiciary, 84th Cong., 2d Sess. I (1956).

85 See Fels, Beyond the Stopwatch: Determining Appellate Venue on Review of FERC Orders, 1 ENERGY L.J. 35, 38-39 (1980); Comment, supra note 83, at 168-69.

86 Pub. L. No. 85-791, $\$ 2,72$ Stat. 91 I (1958), as amended by Pub. L. No. $89-773, \S 5(\mathrm{a}), 80$ Stat. 1323 (1966) (codified at 28 U.S.C. $\$ 2112(\mathrm{a})(1976)$ ).

$87 \mathrm{Id}$.

88 See, e.g., Pearce v. Director, Office of Workers' Compensation Programs, 603 F.2d 763, 771, n.3 (9th Cir. 1979) (collecting the cases by circuit); Dayton Power \& Light Co. v. EPA, 520 F.2d 703, 708 (6th Cir. 1975); Farah Mfg. Co. v. NLRB, 481 F.2d 1143, 1145 (8th Cir. 1973); 15 WrIGHT \& MIILER, supra note $4, \S 3816$, at 102 n.6.

This Article will refer to transfers under either the power explicitly granted by $\$ 2112(a)$ or a court's inherent power to transfer as "discretionary transfer."

89 In most cases the loser of the race apparently concedes, and the litigation proceeds in the circuit of first filing. When discretionary transfers have been requested the requests have been granted approximately one-half of the time. See note 152 infra.

90 At least one loser has argued that $\$ 2112$ (a) should be read so as to make the filing of multiple petitions "simultaneous" if occurring on the same day. See Ball v. NLRB, 299 F.2d 683, 686 (4th Cir.), cert. denied, 369 U.S. 838 (1962). Such a reading would substantially reduce the possibility of inordinately hectic races, although it may create a well-nigh intolerable threat to judicial comity because petitions could be filed in several circuits. See notes 50-58 supra \& accompanying text. In any case, this idea was rejected early on in favor of the current "hour and minute" (and "second") rule. See Ball v. NLRB, 299 F.2d at 686-87.

91 FERC Docket Nos. CI75-45, et al. 
ing on requests by several interstate pipelines for authorization to transport natural gas produced in the offshore federal domain to several onshore gas consuming facilities. ${ }^{92}$ Petitions for review were filed in the Fifth and District of Columbia Circuits at approximately 3:02 p.m. EDT. The Fifth Circuit, pursuant to its own rules of procedure, ${ }^{93}$ referred the matter to FERC for findings as to which party filed first. ${ }^{94}$ Holding that the ultimate finding of who won the race "is a question that must ultimately be resolved by the courts of appeals," the Commission ordered the Administrative Law Judge (ALJ) "to conduct such proceedings as he considers necessary" and to file a report to the Commission.95

The ALJ gamely followed these instructions, and held three days of hearings at FERG headquarters, the District of Columbia Circuit courthouse and the Fifth Circuit courthouse, during which the parties reenacted the race. ${ }^{96}$ According to the ALJ's findings, Tenneco had a five-person line-of-sight human chain from the FERG offices on the first floor to an open telephone line on the second floor. Three reenactments of the sequences resulted in findings of $2.11,1.16$, and 0.95 seconds for this link in the chain. ${ }^{97}$ At the other end of the telephone line, Tenneco maintained a twoman chain to await the signal in the federal courthouse in New Orleans. ${ }^{98}$ Another petitioner, Air Products, took the Commission at its word that it would release its decision at precisely 3:00 p.m. EDT and filed a petition in the Fifth Circuit at 3:01 p.m. EDT, prior to the signal from Tenneco's human chain.

The Public Service Commission of the State of New York, which was racing to the District of Columbia Circuit, prepared two human chains, one being a subterfuge to confuse the timing of Tenneco's chain. After three trial runs the ALJ calculated that the Public Service Commission's chain, which ran across a courtyard to another building, consumed between 1.36 and 1.84 seconds.

92 Tenneco Oil Co., FERC Docket Nos. CI75-45, et al., Opinion No. 10A, (June 21, 1978).

$93 \mathrm{See}$ 5TH CR. R. 11.5.

94 Air Prods. \& Chem., Inc. v. FERC, No. 78-2011 (5th Cir. Oct. 30, 1978) (per curiam order). The District of Columbia Circuit acquiesced in this procedure. Public Serv. Comm'n v. FERC, No. $78-1573$ (D.C. Cir. Nov. 8, 1978) (per curiam order).

95 Tenneco Oil Co., Order Establishing Additional Proceeding Pursuant to Court Order 3, FERC Docket Nos. CI75-45, et al. (Nov. 20, 1978).

98 Tenneco Oil Co., Findings of Fact, Pursuant to Court Order, Concerning Filings of Petitions for Review of FERC Opinion Nos. 10 and 10-A, FERC Docket Nos. Cl75-45, et al., at 2 (March 28, 1979).

${ }_{97} I d$. app. 4.

98 Id. app. 5. 
Another chain at the District of Columbia Circuit courthouse relayed the message to a Public Service Commission operative at the District of Columbia Circuit timeclock. ${ }^{99}$

The ALJ set forth the above factual findings and the Commission adopted them. The Fifth Circuit, however, was dissatisfied with the Commission's action, because the Commission had made findings accurate to the second with respect to only one party. The court, therefore, remanded once again to the Commission for "tothe-second" findings for both parties and an ultimate finding as to which party filed first. ${ }^{100}$ The Commission referred the matter back to the ALJ, ${ }^{101}$ who responded with an elaborate chart that related the events to the hundredth of a second.102 Because Tenneco had begun its process slightly before the order had been stamped in the FERC office, the ALJ found that Tenneco won the race, although he admitted that his conclusion was "based more on perception and probability than upon any demonstrable fact." 103

\section{A. The Cost of the Race}

The mere telling of this tale vividly demonstrates one of the major failings of the first-to-file rule as currently administered-it is a foolish waste of judicial, administrative, and client resources. The Office of the Federal Register has in fact complained that the presence of lawyers in its offices waiting for some race or another to begin interferes with its work. ${ }^{104}$ A conservative estimate of the expenses of a more recent race for review of a FERC order yields a cost to clients of $\$ 65,000 .{ }^{105}$ To this must be added the expense to

99 Id. app. 5-7.

100 Air Prods. \& Chem., Inc. v. FERC, No. 78-2011 (5th Cir. July 19, 1979) (per curiam order).

101 Tenneco Oil Co., Order Remanding Proceeding to Administrative Law Judge for Supplemental Report, FERC Docket Nos. CI75-45 et al. (Aug. 16, 1979).

102 Tenneco Oil Co., Additional Findings of Fact, Pursuant to Court Order, Concerning Filings of Petitions for Review of FERC Opinion Nos. 10 and 10-A, FERC Docket Nos. CI75-45, et al., at app. 3-4 (Sept. 20, 1979).

$103 \mathrm{Id}$. app. 5. For other recent accounts of this race, see Cook, Racing to the Courthouse: Is Justice Left Behind?, INDUSTRY WeEK, May 26, 1980, at 44; Fels, supra note 85 , at $35-36$.

104 See Final EPA Race Regulations, supra note 17, at 26,047 n.5.

105 The race, as related to the author by one of the participants, involved three racers-two to the Fifth Circuit and one to the District of Columbia Circuit. Both Fifth Circuit petitioners maintained open conference telephone lines to the Fifth and District of Columbia Circuits from FERC headquarters. Both had two paralegals and one part-time lawyer in New Orleans, one paralegal and two parttime lawyers at FERC headquarters, and one paralegal at the District of Columbia Circuit for nine hours a day for ten working days. The District of Columbia peti- 
the government of administrative and judicial hearings on who won the race and on the threshold transfer issue. The litigation costs to both parties and the government could thus easily exceed $\$ 100,000$ in a typical case. That other circuits do not appear to be as insistent as the Fifth Circuit that the agencies determine the winner of the race with split second accuracy, ${ }^{106}$ reduces these latter expenditures somewhat in those circuits. Nevertheless, the cost to clients continues to climb as racing techniques grow increasingly sophisticated.

\section{B. The Fairness of the Race}

If races-to-the-courthouse are allowed to determine the appropriate forum for the appeal, it is necessary to ensure that the race be conducted fairly. The need for fairness occasionally requires the courts to act as referees. For example, in the previously described race-to-the-courthouse for review of OSHA's benzene standard, ${ }^{107}$ Judge Leventhal cast the deciding vote in favor of transfer from the circuit of first filing to the Fifth Gircuit because he believed that the Assistant Secretary's private meeting with the union and several industry representatives-before making her decision available to the rest of the parties and the general publicgave some parties an unfair head start. ${ }^{108}$

Agency service by mail poses additional fairness problems, because it gives an inherent advantage to the parties living closest to

tioner maintained one paralegal and one part-time lawyer at FERC headquarters and at the District of Columbia Circuit, and an open local telephone line between the two points. Because the Fifth Circuit ruled that an appeal was not ripe until after the agency had ruled on a motion for rehearing, the race had to be run once again. The second time, however, only one Fifth Circuit petitioner raced and the parties were required to be prepared for only four working days.

106 In United Steelworkers v. Marshall, 592 F.2d 693 (3d Cir. 1979), the court ruled that petitions that were filed within the same minute were simultaneously filed, despite arguments that one petition was filed ten seconds earlier than the other. See also American Pub. Gas Ass'n v. FPC, 555 F.2d 852 (D.C. Cir. 1976) (court accepts agency's finding that the petitions were filed simultaneously); Municipal Distribs. Group v. FPG, 459 F.2d 1367, 1368 (D.C. Cir. 1972) ("We are by no means confident that the difference of two seconds in the stamped filing time of the petitions . . . is sufficiently meaningful to establish the automatic application of the mandate of 28 U.S.C. $\$ 2112$ (a) . . . "); International Union of Elec. Radio \& Mach. Workers v. NLRB, 343 F.2d 327,329 (D.C. Cir. 1965) (court accepts agency's conclusion that neither party can be said to be the first to file). But see Abourezk v. FPC, 513 F.2d 504, 505 (D.C. Cir. 1975) (even though time stamps on pleadings indicated that clocks of the courthouses were not accurate enough to determine winner of race, litigants entitled to "an examination delving beyond the four corners of the pleadings").

107 See text accompanying notes 20-39 supra.

108 Industrial Union Dep't v. Bingham, 570 F.2d 965, 972-73 (D.C. Cir. 1977) (opinion of Leventhal, J.). 
Washington, D.C. ${ }^{109}$ Similarly, mail service poses the ever-present possibility of a mail mix-up that penalizes one party through no fault of its own. In International Union of Electrical, Radio and Machine Workers $v$. NLRB, ${ }^{110}$ for example, the agency, following standard procedure, announced its decision by mail. Some copies were to be sent by registered mail and others were to be sent by first class mail. Although both sets of letters were delivered to the agency's mail room at the same time, the Postal Service inexplicably picked up the first class mail on one day and the registered mail on the next. The union, which was on the first class mailing list, consequently received its copy of the decision before the parties on the registered mail list and filed the first petition for review. Rejecting the company's contention that the unfairness of the notification procedure required transfer to another circuit, the court agreed with Judge Wilkey's opinion in Industrial Union Department $v$. Bingham ${ }^{111}$ that there is no practical way to ensure that all parties are informed simultaneously:

What the appearance of justice requires is that the notification procedure utilized be one fairly designed to afford affected parties an equal opportunity to gain adequate knowledge of the agency action. The first class mail service in these cases did not in fact result in actual notice of the Board's decision to all parties at the same time, but it would be inaccurate to say that the opportunities were skewed from the outset. ${ }^{112}$

The court thus apparently concluded that if a notification mechanism is not inherently biased in favor of a single participant, a court will not inquire into its unfair application in individual cases. While this is perhaps justifiable under the "sporting" theory that the next Postal Service errors might just as easily work to a union's detriment, the court's explanation was probably not satisfying to the companies that lost the unfair race. The real lesson of International Union, however, is the implications that it has for the inherent fairness of a system that depends so critically upon the

109 See International Union of Elec., Radio \& Mach. Workers v. NLRB, 610 F.2d 956, 963-64 (D.C. Cir. 1979); Comment, supra note 83, at 171-72. This problem is ameliorated somewhat by the prevailing practice of large corporate litigants of hiring Washington, D.C. counsel, and the increasing trend of law firms outside that city to open Washington, D.C. offices. See Lewin, Law Firms Branch Out, Go National, Nat'l L.J., Aug. 7, 1978, at 1, col. 4.

110610 F.2d 956 (D.G. Cir. 1979).

111570 F.2d 965, 976 (D.C. Cir. 1977) (opinion of Wilkey, J.).

112610 F.2d at $963-64$ (emphasis in original). 
Postal Service, battery-operated courthouse clocks, and the speed with which secretaries and court clerks open their mail. ${ }^{113}$

More fundamentally, in the relatively rare cases in which there is a large disparity in the parties' wealth, one might legitimately question a system that allows the party with the resources to afford open long-distance telephone lines and sophisticated electronic equipment to choose the forum for review. In the typical FERC case the petitioners are equally well endowed to afford a sophisticated courthouse race. Similarly, the capacity of labor unions to absorb the cost of race is not far different from that of their employer antagonists. Consumer and environmental groups, however, often operate on shoestring budgets, and it seems less fair to require them to race on the same terms as their industrial opponents. ${ }^{114}$

\section{The Starting Pistol}

Because a false start can just as easily result in a defeat as a slow pace, ${ }^{115}$ the parties all have a legitimate concern that there be an agreed upon starting gun. Nevertheless, most agencies have until very recently taken a lackadaisical attitude toward designating the moment in time at which an order is ripe for review, leaving the parties to fight about that question at the appellate level. In the previously described race-to-the-courthouse for review of OSHA's benzene temporary standard, ${ }^{116}$ for example, Judge Wilkey felt that the court did not even have jurisdiction to order transfer to the Fifth Gircuit. In his opinion the union had jumped the gun when it filed its petition immediately after a private meeting with the Assistant Secretary, without waiting for the agency to inform the public through a press conference. ${ }^{117}$ Because the agency action

113 See City of Chicago v. FPC, 360 F.2d 828 (D.C. Cir. 1965) (although petitions were received on the same morning by two courts of appeals, $\$ 2112$ (a) requires that record remain in circuit in which clerk first stamped petition with a docket number).

114 See Letter from J. Taylor Banks, Natural Resources Defense Council, Inc. to Joan Z. Bernstein, General Counsel, EPA (Feb. 20, 1979), reprinted in 44 Fed. Reg. 32,008 (1979).

115 See Southland Mower Co. v. CPSC, 600 F.2d 12 (5th Cir. 1979) (dismissing several petitions as premature); Industrial Union Dep't v. Bingham, 570 F.2d 965, 973 (D.C. Cir. 1977) (opinion of Wilkey, J.); cf. J.P. Stevens \& Co. v. NLRB, 592 F.2d 1237, 1239 (4th Cir. 1979) (court transfers to Second Circuit for determination whether union filed too soon); Fels, supra note 85, at 40-42.

116 See notes 20-39 supra \& accompanying text.

117 Industrial Union Dep't v. Bingham, $570 \mathrm{~F} .2 \mathrm{~d}$ at $974-75$ (opinion of Wilkey, J.) (citing Saturn Airways, Inc. v. CAB, 476 F.2d 907 (D.C. Cir. 1973), in which the court held that an agency order was ripe for review at the time the agency made its decision public through a press release). 
was not in his opinion ripe for review at the time the union filed its petition, the court did not have jurisdiction to entertain the appeal. ${ }^{118}$ Although no court has yet disqualified a racer for a false start, ${ }^{119}$ the threat is always present, and it remains a fertile source for additional threshold litigation.

At the other extreme, the unwary practitioner can discover that the race has already ended before he has even assumed his position at the starting blocks. Ripeness for review is a protean concept, ${ }^{120}$ and the attorney who wants to win must be awake to any agency action that might render the agency proceeding ripe for review. For example, in Saturn Airways, Inc. v. $C A B,{ }^{121}$ the petitioner who waited until the agency released the actual text of its regulations discovered that it had lost the race to the petitioner who had filed immediately after the agency had issued a press release describing the regulations..$^{122}$ Counsel must also be aware of the agency's statute or regulations governing the status of an order that is subject to a motion for reconsideration. If such a

118 Id.

119 See Westinghouse Elec. Corp. v. NRC, 598 F.2d 759, 765-69 (3d Cir. 1979) (petitions filed after order terminating environmental impact proceedings, rather than after release of statement of reasons for order, not premature); Kronenberger v. NLRB, 496 F.2d 18 (7th Cir. 1974) (petition filed immediately after order, rather than after agency ruling on motion for reconsideration, not premature); Saturn Airways, Inc. v. CAB, 476 F.2d 907 (D.C. Cir. 1973) (petition filed after press release, rather than after release of text of order, not premature).

120 See generally K. Davis, Adminstrative Law of twe SeVEntmes $\$ \S 21.06$ 21.07 (1976); K. Davis, Admonsstrative Law Treatise $\$ \$ 21.06-21.07$ (1958).

121476 F.2d 907 (D.C. Cir. 1973).

122 See also Westinghouse Elec. Corp. v. NRC, 598 F.2d 759, 765-68 \& n.21 (3d Cir. 1979) (statement of reasons need not accompany an administrative order to make that order "final" and hence ripe for review; petitioner who waited for statement of reasons consequently lost the race).

See also ITT World Communications, Inc. v. FCC, 621 F.2d 1201 (2d Cir. 1980 ), in which a Second Circuit panel split over determination of the appropriate starting gun. In that case, the FCC on December 12 adopted an order in a public meeting accompanied by a news release, but without a formal written opinion. The formal opinion was not released until some three weeks later. At issue was whether the order was ripe for review for the purposes of $\$ 2112(\mathrm{a})$ as of December 12. Judge Mansfield, joined by Judge Lumbard, opined that, unless the agency specifies an effective date, an order becomes ripe for review when announced at a meeting where "all parties [have] an equal opportunity to learn fairly and simultaneously of the Commission's action and of the terms of its order and decision." Id. 1209 (Mansfield, J., concurring); accord note 31 supra. Judge Newman, on the other hand, advocated an entirely different approach. If the point at which the order is ripe for review is ambiguous, as he felt it was in this case, then he advised abandoning the first-to-file rule and following a "convenience of the parties" test. See 621 F.2d at 1206-07; notes 153-58 infra \& accompanying text. Judge Newman admitted that unless an agency specifies a time at which an order becomes effective, the time at which the order becomes ripe will generally be ambiguous. See 621 F.2d at 1207 n.8. Thus, this proposed exception could swallow the first-to-file rule. It remains to be seen if other circuits will respond more favorably to Judge Newman's suggestion than did his colleagues on the panel. 
motion is required, then the only appropriate time for filing an appeal is after the agency has ruled on the motion..$^{123}$ When the agency has not specified by regulation whether a motion for reconsideration is required, the party that awaits the agency's final ruling on the motion can discover that the race was over weeks ago when the petition for review of the original agency action was filed.124

The lesson that the diligent attorney can draw from this is that it is prudent to file a petition for review after every agency movement that might conceivably be construed as the starting gun. If the attorneys for all of the parties are equally diligent, the result can be not one, but many sophisticated races to the courthouse for review of a single agency action. The reductio ad absurdum of this approach is the classic Shell Oil Co. v. FPC ${ }^{125}$ race in which innovative attorneys beat the system by preparing multiple copies of a single petition and filing them at two second intervals on either side of the time that the agency's decision was expected.126 The circuit in which this occurred did not question the fairness of this procedure, noting only that such forum shopping is "inherent in the statute." 127

123 See American Pub. Gas Ass'n v. FPC, 555 F.2d 852, 856 (D.C. Cir. 1976) ("Under the Natural Gas Act, an order lacks jurisdictional ripeness for review until the Commission has disposed of a petition to reconsider alleged error in it (or until a reasonable time to act upon such petition has expired).").

124 See Kronenberger v. NLRB, 496 F.2d 18 (7th Cir. 1974).

125509 F.2d 176 (5th Cir. 1975).

126 Id. 179. All of the earlier petitions were, of course, premature, but the petitioners virtually guaranteed themselves the first filing, so long as they did not run out of petitions.

127 Id.

Attorneys for the American Petroleum Institute (API) recently came up with another way to stack the odds in their own favor in their race to the courthouse. OSHA's promulgation of its generic carcinogen standards on January 18, 1980 precipitated a race to the Fifth and District of Columbia Circuits by the API and AFL-CIO respectively. The API won the race, but it may have done so only by jumping the starting gun. The AFL-CIO asked for transfer to the District of Columbia on this and other grounds.

Perhaps in order to enhance the chances that the Fifth Circuit would decide to retain venue, attorneys for API filed three suits in Texas federal district court challenging the carcinogen standards. When the district court summarily dismissed the suits on jurisdictional grounds, the Institute appealed the dismissal to the Fifth Circuit, and then pointed to the pending appeal as a reason militating in favor of the Fifth Circuit retaining jurisdiction over the challenge to the standards originally filed in that court. This bootstrapping apparently succeeded because the Fifth Circuit cited to the pending appeal as one reason in support of its decision to retain venue. See American Petroleum Inst. v. OSHA, Nos. 80-3051 et al. (5th Cir. Sept. 15, 1980) (unpublished order).

Even more distressing than the threat of multiple races is the possibility that a party will file a bogus action for emergency relief under the All Writs Act, 28 U.S.C. $\$ 1651$ (1976), before an appeal would otherwise be ripe in an attempt to establish priority under $\$ 2112(a)$. Fortunately, the only court in which this ploy has been attempted has rejected it outright. See American Pub. Gas Ass'n v. FPC, 555 F.2d 852, 856-57 (D.C. Cir. 1976). 


\section{The Scope of the Agency Action}

Section 2112(a) provides for consolidation of appeals from "the same order" in the circuit in which the first petition was filed.128 Given the rich variety of agency actions that section 2112 (a) attempts to address, its oblique reference to the "same order" has, not surprisingly, proven unsatisfactory. Because a single administrative proceeding can address multiple parties, products, and issues, controversy can arise over whether the result of a proceeding is a single order or a series of separately issued orders.

\section{Single Agency Action}

Most agency proceedings are terminated by a single agency action. Courts appear to be confused about how such actions should be treated under the "same order" requirement of section 2112(a). For example, in Bristol Laboratories, Inc. v. Richardson, ${ }^{129}$ the Food and Drug Administration (FDA) addressed in a single decertification proceeding "a group of fifteen fixed-combination drugs having common characteristics and subject to common criticisms" and concluded the proceeding by issuing a single order. ${ }^{130}$ American Cyanamid filed the first petition for review in the First Circuit. ${ }^{131}$ Bristol filed a later appeal in the Third Circuit, which was promptly transferred, pursuant to section 2112(a), to the First Gircuit. In its motion to have its petition retransferred to the Third Circuit, Bristol claimed that the FDA order issued at the conclusion of its proceeding was really several orders, only one of which was addressed to Bristol and its product. The court denied the motion, noting its hesitancy "to ignore the unitary label given the order." 132 The court concluded that

To consider the order atomized because of its application to several products, although those products are substantially similar in composition and therapeutic theory and their use presented a common problem dealt with in a single decertification proceeding, does not appear to comport with either the letter or spirit of $\S 2112(\mathrm{a}) .{ }^{133}$

12828 U.S.C. $\$ 2112$ (a) (1976). See note 6 supra for full statutory text.

The "same order" requirement, a condition precedent to the invocation of the first-to-file rule of $\$ 2112(\mathrm{a})$, should be distinguished from the "similar proceedings" branch of the alternatively available discretionary transfer mechanism. See text accompanying notes 169-71 infra.

129456 F.2d 563 (1st Cir. 1971).

130 Id. 565.

131 See American Cyanamid Co. v. Richardson, 456 F.2d 509 (Ist Cir. 1971). 132456 F.2d at 564 .

${ }^{133} I d .564-65$. 
By contrast, the court in Far East Conference v. FMC ${ }^{134}$ refused to accept the agency's definition of the scope of its order. In that case the Federal Maritime Commission, as part of a generic proceeding concerning a "Foreign Trade Study," issued several identical orders requesting information from the various maritime freight conferences. The first challenges to the Commission's authority to issue the orders were filed in the Ninth Circuit. Later appeals were filed in the District of Columbia Circuit. The Commission moved to transfer the appeal to the Ninth Circuit on the ground that the petitions were for review of the same order. The District of Columbia Circuit denied the motion, stating only that "the orders themselves cannot be considered the 'same order' within the meaning of the statute." 135

The results in Bristol Laboratories and Far East Conference are difficult to reconcile. That the former involved a unitary order while the latter involved, as a formal matter, multiple orders is a distinction without a difference. Courts generally look to the substance of the agency action when determining whether or not such action constitutes the "same order" under section 2112(a); 130 the orders issued in Far East Conference were absolutely identical except for the target party's name. While Bristol Laboratories represents a salutary attempt by a court to avoid wasting judicial and client resources, the court in Far East Conference, by adhering to an extremely narrow definition of "same order," decided to forego a similar opportunity.

\section{Successive Agency Actions}

Agencies can issue many appealable final orders during the course of a single proceeding or related proceedings. If, at the end of the proceedings, no separate appeals have been taken, the courts are likely to characterize the final order that concludes the proceeding as a single order subject to review in a single court. ${ }^{137}$ Similarly, when two orders have emanated from two formally separate and unrelated proceedings, they probably will not be characterized as a "single order." 138

134337 F.2d 146 (D.C. Cir. 1964), cert. denied, 379 U.S. 991 (1965).

135 Id. 148 n.l.

136 See notes $137-49$ infra \& accompanying text.

137 See American Civil Liberties Union v. FCC, 486 F.2d 411, 414 (D.C. Cir. 1973) ("The several orders issued in the course of that proceeding represent the staggered implementation of a single, multi-faceted agency undertaking.").

138 See American Tel. \& Tel. Co. v. FCC, 519 F.2d 322 (2d Cir. 1975) (order setting rate of return for AT\&T and later order rejecting proposed increase because 
Even these reasonably straightforward rules, however, are often difficult to apply to the remarkable diversity of appealable agency actions. In BASF Wyandotte Corp. v. Costle, ${ }^{139}$ for example, the EPA, pursuant to a court order, ${ }^{140}$ had issued proposed regulations establishing effluent limitations guidelines for the pesticides industry. Because of the pressure of the court order, EPA made the proposed regulations effective immediately, but subject to change after comment from interested parties. The proposed regulations were therefore in effect final interim regulations. Several companies petitioned for review of the proposed regulations; the first petition was filed in the First Circuit. Approximately two years later, EPA published final regulations, which amended the proposed regulations in many respects. One pesticide company filed a petition for review of the final regulations in the Fifth Circuit. The First Circuit petitioner then simply amended its complaint to include the final regulations. Relying on dicta from the District of Columbia Circuit, ${ }^{141}$ the First Circuit held that sequential regulations should be considered the same order if they arise from the "same or interrelated proceedings." ${ }^{142}$ Because the EPA proceedings met that test, the court held that the two orders, even though separated by two years, were in fact the same order. The First Circuit was therefore the circuit of the first filed petition.

Although the courts have not been entirely consistent, ${ }^{143}$ the $B A S F$ Wyandotte "same or interrelated proceedings" test adequately characterizes the holdings in cases in which the prior successive order is pending in a court of appeals at the time the second order is issued. ${ }^{144}$ When one court has already disposed of an appeal

it would result in higher rate of return than first order allowed are not the "same order"; however, case transferred under court's "inherent power" to transfer). 139582 F.2d 108 (1st Cir. 1978).

140 Natural Resources Defense Council, Inc. v. Train, 396 F. Supp. 1393 (D.D.C. 1975), aff'd sub nom. Natural Resources Defense Council, Inc. v. Costle, 568 F.2d 1369 (D.C. Cir. 1977).

141 See Public Serv. Comm'n v. FPC, 472 F.2d 1270, 1272 (D.C. Cir. 1972);

Eastern Air Lines, Inc. v. CAB, 354 F.2d 507, 510 (D.C. Cir. 1965).

142582 F.2d at 112.

143 Compare Midwest Video Corp. v. United States, 362 F.2d 259 (8th Cir. 1966) (court refuses to retain appeal from order regulating all cable television systems when petitions to review order regulating only microwave cable television systems are presently pending before the court) with Midwest Television, Inc. v. FCC, 364 F.2d 674 (D.C. Cir. 1966) (court transfers appeal from board plan to regulate cable television to circuit in which petitions for review of previously issued narrow rules on the same subject matter are currently pending).

144 See Public Interest Research Group v. FCC, 522 F.2d 1060 (1st Cir. 1975), cert. denied, 424 U.S. 965 (1976) (court refuses to transfer petition for review of denial of fairness doctrine complaint to circuit reviewing previously issued generic fairness doctrine report because no clear showing made that the two proceedings are sufficiently interrelated). The court in Public Serv. Comm'n v. FPC, 472 F.2d 
from one of two or more successive orders in a single proceeding, however, the courts typically require the parties to run a new race, even if the orders are very closely related. ${ }^{145}$ American Civil Liberties Union $v$. FCC ${ }^{146}$ is an excellent example. In the course of protracted proceedings concerning cable television, the Commission issued numerous appealable orders. The American Givil Liberties Union (ACLU) petitioned for review of a June 26, 1972 order, and the District of Columbia Circuit summarily disposed of that appeal on April 6, 1973.147 On April 2, 1973, the ACLU petitioned for review of apparently another aspect of the June 26, 1972 order and of a January 31, 1973 order which terminated the entire proceeding. Although another party had won the race for review of the January 31, 1973 order in the Ninth Circuit, the ACLU argued that the June 26 order was the "same order" for purposes of section 2112(a). The court disagreed, holding that "[i]t is not possible to consolidate a pending petition with one involved in litigation which has ended." 148 On the other hand, the court held that the June 26, 1972 and January 31, 1973 orders were the same order for purposes of deciding issues that remained open after the first appeal. The court, therefore, ordered transfer to the circuit in which the first petition for review of the January 31, 1973 order had been filed, despite the fact that no appeal from the June 26, 1972 order had been filed in that circuit. Thus, the court took a liberal view toward combining pending successive orders into a single order for purposes of section 2112(a), but refused to combine two successive orders when an appeal from one of them had already been decided. ${ }^{148}$

1270 (D.C. Cir. 1972) articulated a very narrow test for the term "interrelated": "[T]he 'interrelated" term refers to an organic relation in what may fairly be called a single 'total proceeding' and not merely similarity of legal issues." Id. I272 n.4. But cf. American Tel. \& Tel. Co. v. FCC, 519 F.2d 322 (2d Cir. 1975) (court indicates that order granting individual rate increase and previous order setting overall rate of return could be "same order" under $\$ 2112(a)$; court transfers under its inherent powers).

145 One court has hinted at a possible exception to this general rule in situations in which a petition is "brought for review of an order entered after remand." Public Serv. Comm'n v. FPC, 472 F.2d 1270, 1272 (D.C. Cir. 1972). However, the only direct precedent is equivocal. See Pacific Gas \& Elec. Co. v. FPC, 272 F.2d 510 (D.C. Cir. 1958) (circuit court has discretion to either transfer or hear the case).

146486 F.2d 411 (D.C. Cir. 1973). See also Pan Am. World Airways, Inc. v. CAB, 380 F.2d 770 (2d Cir. 1967), aff'd by an equally divided Court, 391 U.S. 461 (1968); Far East Conference v. CAB, 337 F.2d 146 (D.C. Cir.), cert. denied, 379 U.S. 991 (1964).

147 National Ass'n of Theater Owners v. FCC, 477 F.2d 450 (D.C. Cir. 1973). 148486 F.2d at 414.

149 The Ninth Circuit retained jurisdiction over the petition that had been transferred to it and decided that case even after it had remanded the first insti- 


\section{E. Discretionary Transfer}

Courts have broad authority under section 2112(a) to transfer a case to any other circuit "[f]or the convenience of the parties in the interest of justice." 150 Courts have also spoken of an "inherent power" to transfer to a more appropriate circuit.151 In addition to pressing for transfer because of an allegedly unfair race, litigants have argued that courts should order discretionary transfer because another circuit is more convenient, because another circuit is more affected by the agency ruling, or because other orders from the same or similar administrative proceeding are pending in or have been decided by another circuit. Only the latter two arguments have met with much success in the courts of appeals. ${ }^{152}$

tuted proceedings to the Commission. See American Civil Liberties Union v. FCC, 523 F.2d 1344, 1346 (9th Cir. 1975).

15028 U.S.C. $\$ 2112$ (a) (1976).

As a matter of statutory interpretation, it is not clear exactly how the phrases "for the convenience of the parties" and "in the interest of justice" interrelate. As a starting point, it can be safely stated that the two phrases should not be read disjunctively. Such a reading would permit a court to order a transfer that would be convenient but not in the interests of justice. See S. REP. No. 2129, 85th Cong., $2 d$ Sess., reprinted in [1958] U.S. CoDE Cong. \& AD. NEws 3996. But beyond this, it is questionable whether one criterion is primary to the other. At least one judge has argued that transfer may be effected only for convenience; the justice requirement serves merely to provide a reason not to transfer. See Industrial Union Dep't v. Bingham, 570 F.2d 965, 979 \& nn.4, 6 (D.C. Cir. 1977) (Fahy, J., dissenting). Most courts, however, appear to feel that the convenience requirement limits the "in the interests of justice" requirement. See notes 154-55 infra \& accompanying text. Thus, as long as a transfer was not inconvenient to a party, a court could order a transfer solely "in the interest of justice."

151 See note 88 supra.

152 The author has discovered twenty-two published or otherwise reported opinions in which a court has been asked to transfer pursuant to its "inherent power" or pursuant to the "in the interest of justice for the convenience of the parties" provision of $\$ 2112$ (a). ITT World Communications, Inc. v. FCC, 621 F.2d 1201 (2d Cir. 1980); International Union of Elec., Radio \& Mach. Workers v. NLRB, 610 F.2d 956 (D.C. Cir. 1979); Southland Mower Co. v. CPSC, 600 F.2d 12 (5th Cir. 1979); United Steelworkers v. Marshall, 592 F.2d 693 (3d Cir. 1979); Weyerhaeuser Co. v. Costle, 590 F.2d 1011 (D.C. Cir. 1978); Industrial Union Dep't v. Bingham, 570 F.2d 965 (D.C. Cir. 1977); American Pub. Gas Ass'n v. FPC, 555 F.2d 852 (D.C. Cir. 1976); Public Interest Research Group v. FCC, 522 F.2d 1060 (1st Cir. 1975), cert. denied, 424 U.S. 965 (1976); American Tel. \& Tel. Co. v. FCC, 519 F.2d 322 (2d Cir. 1975); Farah Mfg. Co. v. NLRB, 481 F.2d 1143 (8th Cir. 1973); Saturn Airways, Inc. v. CAB, 476 F.2d 907 (D.C. Cir. 1973); Public Serv. Comm'n v. FPC, 472 F.2d 1270 (D.C. Cir. 1972); Municipal Distribs. Group v. FPC, 459 F.2d 1367 (D.C. Cir. 1972); J.L. Simmons Co. v. NLRB, 425 F.2d 52 (7th Cir. 1970); J.P. Stevens \& Co. v. NLRB, 388 F.2d 892 (4th Cir. 1967); Pan Am. World Airways, Inc. v. CAB, 380 F.2d 770 (2d Cir. 1967), aff'd by an equally divided Court, 391 U.S. 461 (1968); J.P. Stevens \& Co. v. NLRB, No. 11,246 (4th Cir. Apr. 10, 1967) (unpublished order) (discussed in J.P. Stevens \& Co. v. NLRB, 388 F.2d 892 (4th Cir. 1967)) ("Stevens II"); International Union, UAW v. NLRB, 373 F.2d 671 (D.C. Cir. 1967); Midwest Television, Inc. v. FCC, 364 F.2d 674 (D.C. Cir. 1966); Insurance Workers Int'l Union v. NLRB, 360 F.2d 823 (D.C. Cir. 1966); Eastern Air Lines, Inc. v. CAB, 


\section{Convenience of the Parties}

The convenience of the parties is explicitly included in section 2112(a) as a consideration for discretionary transfer. ${ }^{153}$ Yet while the parties have occasionally urged that transfer to another court would be more convenient, ${ }^{154}$ no court has transferred on this basis alone. ${ }^{155}$ Because each party can usually make a reasonably plausible argument that the circuit of its choice is most convenient, ${ }^{156}$ it is not surprising that the courts have not made convenience a major factor in transfer decisions. Indeed, one pragmatic court has recognized that "[t]he only significant convenience factor which affects petitioners seeking review of rulemaking on an agency record is the convenience of counsel who will brief and argue the peti-

354 F.2d 507 (D.C. Cir. 1965); Far East Conference v. FMC, 337 F.2d 146 (D.C. Cir. 1964), cert. denied, 379 U.S. 991 (1965).

In 11 of those cases transfer was ordered. In one case the court apparently transferred because it was concerned about the fairness of the agency's procedures for beginning the race. Industrial Union Dep't v. Bingham, 570 F.2d 965 (D.C. Cir. 1977). In two cases, the court transferred because it held the first-filing party insufficiently aggrieved by the agency action to have its choice of forum. J.L. Simmons Co. v. NLRB, 425 F.2d 52 (7th Cir. 1970); Insurance Workers Int'l Union v. NLRB, 360 F.2d 823 (D.C. Cir. 1966). In the remaining eight cases the court transferred because another petition from the same or similar case had been previously filed or decided. United Steelworkers v. Marshall, 592 F.2d 693 (3d Cir. 1979); Weyerhaeuser Co. v. Costle, 590 F.2d 1011 (D.C. Cir. 1978); American Tel. \& Tel. Co. v. FCC, 519 F.2d 322 (2d Cir. 1975); Farah Mfg. Co. v. NLRB, 481 F.2d 1143 (8th Cir. 1973); Municipal Distribs. Group v. FPC, 459 F.2d 1367 (D.C. Cir. 1972); J.P. Stevens \& Co. v. NLRB, No. 11,246 (4th Cir. Apr. 10, 1967) (unpublished order) (discussed in J.P. Stevens \& Co. v. NLRB, 388 F.2d 892 (4th Cir. 1967)) ("Stevens II"); Midwest Television, Inc. v. FCC, 364 F.2d 674 (D.C. Cir. 1966); Eastern Air Lines, Inc. v. CAB, 354 F.2d 507 (D.C. Cir. 1965).

One should be cautious in interpreting this tabulation, however, because it reflects only those transfers that resulted in published opinions or were otherwise reported.

15328 U.S.C. $\$ 2112$ (a) (1976). See also 28 U.S.C. $\$ 1404$ (a) (1976).

154 See, e.g., United Steelworkers v. Marshall, 592 F.2d 693 (3d Cir. 1979); Industrial Union Dep't v. Bingham, 570 F.2d 965 (D.C. Cir. 1979); American Pub. Gas Ass'n v. FPC, 555 F.2d 852 (D.C. Cir. 1976).

155 While no court has transferred to another circuit on the basis of convenience alone, the District of Columbia Circuit cited the convenience of the parties as a reason for refusing to transfer in a case involving simultaneous filings. American Pub. Gas Ass'n v. FPC, 555 F.2d 852, 857 (D.C. Cir. 1976). See also ITT World Communications, Inc. v. FCC, 621 F.2d 1201, 1208 (2d Cir. 1980). However, in Industrial Union Dep't v. Bingham, 570 F.2d 965 (D.C. Cir. 1977), a case in which three separate opinions were filed, the court transferred the case to the Fifth Circuit, despite opinions by two of the three judges that the District of Columbia Circuit was the most convenient.

156 For example, in United Steelworkers v. Marshall, 592 F.2d 693, 697 (3d Cir. 1979), the Lead Industries Association argued that the Fifth Circuit was more convenient than the Third Circuit because a large number of employers who were aggrieved by OSHA's lead standard were located in the Fifth Circuit. The United Steelworkers replied that 15,000 of its members worked in plants in the Third Circuit. The court quite justifiably declined to decide which of the two circuits was the most convenient for the parties. 
tions." 157 Given the universal use of air travel and long distance telecommunications, it is unlikely that arguing an appeal before a distant court will be significantly inconvenient for counsel. Nor are the additional expenses associated with such travel a significant portion of the cost of an appeal from administrative rulemaking. ${ }^{168}$

\section{Regional Impact of the Agency Action}

Parties in a few cases have urged discretionary transfer on the ground that one circuit is more "affected" by the agency action than another.159 No court has ordered transfer solely on this ground, although it has apparently played some role in two NLRB unfair labor practice cases. ${ }^{160}$ Courts have recognized that it is usually difficult to pinpoint a region that is more affected by a federal administrative action than another, ${ }^{161}$ and they understandably have been reluctant to initiate threshold inquiries into this essentially factual question in deciding whether to use their discretionary transfer power.

\section{Comparative Aggrievement}

Later-filing parties have in numerous cases contended that the first-filing party was not sufficiently "aggrieved" by the agency action to be entitled to its choice of forum, and they have urged the courts to exercise their discretionary power to transfer to the "more aggrieved" party's circuit. Although the courts have stated

157 Id.

153 See 16 WRIGHT AND MrLLER, supra note 4, $\$ 3944$, at 339; Carrington, supra note 74, at 608; Currie \& Goodman, supra note 3, at 8; Fels, supra note 85, at 45 .

159 See International Union of Elec., Radio \& Mach. Workers v. NLRB, 610 F.2d 956, 962 (D.C. Cir. 1979); American Pub. Gas Ass'n v. FPC, 555 F.2d 852, 858 n.5 (D.C. Cir. 1976); Farah Mfg. Co. v. NLRB, 481 F.2d 1143 (8th Cir. 1973); Public Serv. Comm'n v. FPC, 472 F.2d 1270 (D.C. Cir. 1972); J.P. Stevens \& Co. v. NL.RB, No. 11,246 (4th Cir. Apr. 10, 1967) (unpublished order) (discussed in J.P. Stevens \& Co. v. NLRB, 388 F.2d 892 (4th Cir. 1967)) ("Stevens II").

160 See Farah Mfg. Co. v. NLRB, 481 F.2d 1143 (8th Cir. 1973); J.P. Stevens \& Co. v. NLRB, No. 11,246 (4th Cir. Apr. 10, 1967) (unpublished order) (discussed in J.P. Stevens \& Co. v. NLRB, 388 F.2d 892 (4th Cir. 1967)). ("Stevens II"). But see International Union of Elec., Radio \& Mach. Workers v. NLRB, 610 F.2d 956, 962 (D.C. Cir. 1979).

161 See United Steelworkers v. Marshall, 592 F.2d 693, 697 (3d Cir. 1979); American Pub. Gas Ass'n v. FPC, 555 F.2d 852, 859 n.5 (D.C. Cir. 1976); Public Serv. Comm'n v. FPC, 472 F.2d 1270 (D.C. Cir. 1972). Although the courts have not been favorably disposed toward regional impact as a transfer criterion, Congress has been urged to include it explicitly as a criterion. See notes 269-77 and 304-05 infra \& accompanying text. 
in dicta that "a party's selection of forum is [not] necessarily controlling if it has received substantially all of the relief contemplated," ${ }^{162}$ they have ordered transfer on this basis in only two cases. ${ }^{163}$ In one of them, Insurance Workers International Union v. $N L R B,{ }^{164}$ the union challenged the Board's unit designation on two grounds: (1) that it did not include fire insurance agents, and (2) that the Board should have compelled the employer to accept and abide by the terms of the collective bargaining agreement that would have been entered into had the employer bargained in good faith. After holding oral argument and probing the record deeply for evidence on the question, the court rejected the union's first contention because it was factually incorrect. It rejected the union's second argument because it was so speculative that the Board probably would have lacked authority to decide it. The court therefore transferred the case to the Seventh Circuit so that that court could rule on the employer's claim on the merits that all the insurance workers were in fact independent contractors. Interestingly, the court refused to dismiss the union's claims on standing grounds; the court opined that the Seventh Circuit should have an independent opportunity to probe the union's aggrievement. . $^{165}$

Few courts, however, have been as eager as the Insurance Workers court to probe the record on the aggrievement question in making the threshold decision whether to transfer. More recently, courts have cautioned that " $[\mathrm{t}]$ he possibility of a transfer on this ground is not to be taken as permitting a trial by affidavit on the issue of motivation." ${ }^{166}$ It would seem particularly wasteful of

162 International Union, UAW v. NLRB, 373 F.2d 671, 674 (D.C. Cir. 1967). 163 J.L. Simmons Co. v. NLRB, 425 F.2d 52 (9th Cir. 1970); Insurance Workers Int'l Union v. NLRB, 360 F.2d 823 (D.C. Cir. 1966). See also Ithaca College v. NLRB, 623 F.2d 224 (2d Cir. 1980), in which the Second Circuit speculated about the District of Columbia Circuit's stand on the relative aggrievement test for discretionary transfer.

164360 F.2d 823 (D.C. Cir. 1966).

165 The only other case in which transfer was ordered because of the firstfling party was insufficiently aggrieved is J.L. Simmons Co. v. NLRB, 425 F.2d 52 (9th Cir. 1970), in which the employer challenged the Board's order requiring the union to cease and desist from its secondary boycott. Although the Board gave the employer all the relief that it requested, it declined to rule on one of the employer's contentions, because such a ruling was unnecessary to decide the case. Without finding that the employer was not an "aggrieved party" within the meaning of the judicial review section of the National Labor Relations Act, 29 U.S.C. $\S 160$ (f) (1976), the court ruled that the employer's aggrievement did not warrant allowing it to choose the forum for appeal.

166 International Union, UAW v. NLRB, 373 F.2d 671, 674 (D.C. Cir. 1967). See also International Union of Elec., Radio \& Mach. Workers v. NLRB, 610 F.2d 956, 962 (D.C. Cir. 1979); United Steelworkers v. Marshall, 592 F.2d 693, 696 (3d Cir. 1979) ("Certainly the reference to 'the interest of justice" in $\$ 2112(\mathrm{a})$ 
valuable judicial resources to address one party's aggrievement extensively in a threshold transfer proceeding and then leave the aggrievement question open for re-resolution after transfer. Indeed, one year after Insurance Workers was decided, the District of Columbia Circuit limited its use of the comparative aggrievement factor to "the special case where the 'inconsequential' character of the deficiency in findings or relief is established by the petitioner's own stipulation ... or other pleading or representation." 167 Under this narrow test the courts, not surprisingly, have refused to order transfer in the vast majority of cases. ${ }^{168}$

\section{Same or Similar Proceedings in Another Circuit}

In eight of the eleven reported cases in which the courts have ordered discretionary transfer, they have done so because the transferee circuit had previously decided a case arising out of the same or similar administrative proceeding or involving the same or similar issues. ${ }^{169}$ As previously discussed, ${ }^{170}$ courts can order transfer to another court in which a petition from the same or similar

was not intended to require such a preliminary examination of the merits."); Truck Drivers \& Helpers Local 728 v. NLRB, 386 F.2d 643, 644 (D.C. Cir. 1967); Ball v. NLRB, 299 F.2d 683, 689 (D.C. Cir.), cert. denied, 369 U.S. 838 (1962). 167 International Union, UAW v. NLRB, 373 F.2d 671, 674 (D.C. Cir. 1967). See also Public Serv. Comm'n v. FPC, 472 F.2d 1270, 1272 n. 2 (D.C. Cir. 1972) (recognizing the possibility of transfer because of insufficient aggrievement, but limiting it to the same "special case" as International Union, UAW). See also United Steelworkers v. Marshall, 592 F.2d 693, 696 (3d Cir. 1979) ("[C]ourt: have limited the inquiry into the respective merits of the petitions to a determination whether the petitioning party's claim of aggrievement is so frivolous or insubstantial as to undercut the assumption of a good faith petition for review.").

168 See International Union of Elec., Radio \& Mach. Workers v. NLRB, 610 F.2d 956, 962 (D.C. Cir. 1979); United Steelworkers v. Marshall, 592 F.2d 693 (3d Cir. 1979) (transfer granted on other grounds); American Pub. Gas Ass'n v. FPC, 555 F.2d 852, 858 n.5 (D.C. Cir. 1976); Saturn Airways, Inc. v. CAB, 476 F.2d 907 (D.C. Cir. 1973); Truck Drivers \& Helpers Local 728 v. NLRB, 386 F.2d 643 (D.C. Cir. 1967); International Union, UAW v. NLRB, 373 F.2d 671 (D.C. Cir. 1967); Ball v. NLRB, 299 F.2d 683, 689 (4th Cir.), cert. denied, 369 U.S. 838 (1962).

One court, however, has cited relative aggrievement as a reason for denying a motion for transfer. See ITT World Communications, Inc. v. FCC, 621 F.2d 1201, 1208 (2d Cir. 1980).

169 United Steelworkers v. Marshall, 592 F.2d 693 (3d Cir. 1979); Weyerhaeuser Co. v. Costle, 590 F.2d 1011, 1022 (D.C. Cir. 1978); American Tel. \& Tel. Co. v. FCC, 519 F.2d 322 (2d Cir. 1975); Farah Mfg. Co. v. NLRB, 481 F.2d 1143 (8th Cir. 1973); Municipal Distribs. Group v. FPC, 459 F.2d 1367 (D.C. Cir. 1972); J.P. Stevens \& Co. v. NLRB, No. 11, 246 (4th Cir. Apr. 10, 1967) (unpublished order) (discussed in J.P. Stevens \& Co. v. NLRB, 388 F.2d 892, 894 (4th Cir. 1967)) ("Stevens II"); Midwest Television, Inc. v. FCC, 364 F.2d 674 (D.C. Cir. 1966); Eastern Air Lines, Inc. v. CAB, 354 F.2d 507 (D.C. Cir. 1965).

170 See notes $137-49$ supra \& accompanying text. 
administrative order has been filed, but not decided, by broadly interpreting the term "same order." A court's determination that two orders are not the "same order," however, does not end the matter, because the court receiving the first petition in the second race may still order discretionary transfer. ${ }^{171}$ The courts appear to agree that "one circuit's familiarity with the issues and parties from prior litigation" 172 and "the need for continuity and consistency in reviewing a series of agency decisions" ${ }^{173}$ are factors that should be considered in deciding whether discretionary transfer is appropriate, but they also disavorw any theory of "specialization of tribunals." 174 Unfortunately, the courts have been unable to articulate and consistently follow a single rule for striking the delicate balance between judicial economy and generalist courts.

The District of Columbia Circuit made the first attempt to state such a rule in Eastern Air Lines, Inc. $v . C A B .{ }^{175}$ In that case, the First Circuit had twice remanded a Civil Aeronautics Board order denying Northeast Airlines a renewal of its certificate for an East Coast-Florida route. In response to the second remand, the agency on April 26, 1965 reopened the East Coast-Florida proceedings to reconsider entirely the number of carriers that should be allowed on that route and who those carriers should be. The First Circuit, noting that the Board's action went beyond that court's second remand, relinquished jurisdiction. Meanwhile, the other two carriers that owned certificates for the route filed a petition in the District of Columbia Circuit to review the April 26 order. Because the First Circuit had already issued its opinions with respect to the first two agency orders, the District of Columbia Circuit could not rely upon the "same order" rule to order transfer to the First Circuit. ${ }^{176}$ Nevertheless, the court ordered

171 See American Tel. \& Tel. Co. v. FCC, 519 F.2d 322 (2d Cir. 1975) (court declines to decide "same order" question, but orders discretionary transfer).

172 Abourezk v. FPC, 513 F.2d 504, 505 n.1 (D.C. Cir. 1975).

173 Id.

174 See International Union of Elec., Radio \& Mach. Workers v. NLRB, 610 F.2d 956, 963 n.7 (D.C. Cir. 1979); United Steelworkers v. Marshall ,592 F.2d 693, 697 (3d Cir. 1979); American Pub. Gas Ass'n v. FPC, 555 F.2d 852, 857-58 (D.C. Cir. 1976); Public Serv. Comm'n v. FPC, 472 F.2d 1270, 1271-72 (D.C. Cir. 1972); Midwest Television, Inc. v. FCC, 364 F.2d 674, 675 (D.C. Cir. 1966). But cf. Public Interest Research Group v. FCC, 522 F.2d 1060, 1063 (Ist Cir. 1975) (speaking of the "special familiarity of the D.C. Circuit with communications problems").

175354 F.2d 507 (D.C. Cir. 1965).

178 See note 145 supra \& accompanying text. Indeed, because neither of the District of Columbia petitioners had its domicile or principal place of business in the First Circuit, the First Circuit did not even have proper venue. 354 F.2d at 510 . 
discretionary transfer, pointing out that the First Circuit was "familiar with the background of the controversy." 177 The court stated that section 2112(a) "should be liberally applied to permit review by a single court of closely related matters where appropriate for sound judicial administration." 178 Other circuits have followed this "familiar with the background of the controversy" test to varying degrees. ${ }^{179}$

More recently, however, the District of Columbia Circuit has signaled a change in approach. In Public Service Commission $v$. $F P C,{ }^{180}$ that circuit refused to transfer a petition for review of a East Texas Area natural gas rate proceeding to the Fifth Circuit, despite the gas producers' contention that the case and a rate proceeding just reviewed by the Fifth Circuit raised common questions of law and closely related questions of fact. ${ }^{181}$ Four years later, in American Public Gas Association v. FPC, ${ }^{182}$ the District of Columbia and Fifth Circuits received simultaneous petitions to review the second of FPC's nationwide natural gas rate proceedings. The

$177354 \mathrm{~F} .2 \mathrm{~d}$ at 510 .

178 Id. 511. See also Municipal Distribs. Group v. FPC, 459 F.2d 1367 (D.C. Cir. 1972); Midwest Television, Inc. v. FCC, 364 F.2d 674 (D.C. Cir. 1966).

179 See American Tel. \& Tel. Co. v. FCC, 519 F.2d 322, 327 (2d Cir. 1975) (court orders transfer of proceeding on individual rate hikes to court hearing appeal from proceeding prescribing a rate of return for AT\&T; court notes that the transferee circuit is "intimately familiar with the background of this controversy"); Farah Mfg. Co. v. NLRB, 481 F.2d 1143, 1145 (8th Cir. 1973) (court orders discretionary transfer of unfair labor practice case to court that had previously decided cases arising out of the same union organizational drive; court says that the transferee court is "familiar with the background of this case"). But see Pan Am. World Airways, Inc. v. CAB, 380 F.2d 770, 775 (2d Cir. 1967) (refusing to order discretionary transfer of appeal from order permitting international "inclusive tours" to court that had recently decided that the board lacked authority to authorize national "inclusive tours"; court refers to the "very unusual circumstances" of the earlier case); J.P. Stevens \& Co. v. NLRB, 388 F.2d 892 (4th Cir. 1967) (having already transferred one order to court reviewing previous order arising out of the same union organizational effort, court refuses to order discretionary transfer of two subsequent orders).

180472 F.2d 1270 (D.C. Cir. 1972).

181 The court had to contend with a factually similar case decided in the opposite manner only four months earlier. In Municipal Distribs. Group v. FPC, 459 F.2d 1367 (D.C. Cir. 1972), a District of Columbia Circuit panel transferred an order arising out of the Southern Louisiana Area Rate Proceeding to the Fifth Circuit because that court was "familiar with the background of the controversy" through its review of a previous FPC order involving the same proceeding. Id. 1368. The Public Service Commission court distinguished Municipal Distributors on the basis of a fact which the Municipal Distributors court expressly refused to rely upon-that the Fifth Circuit petition in the latter case had been time-stamped two seconds earlier than the District of Columbia Circuit petition. See Public Serv. Comm'n v. FPC, 472 F.2d at 1273; Municipal Distribs. Group v. FPC, 459 F.2d at 1368 .

182555 F.2d 852 (D.C. Cir. 1976). 
Fifth Circuit had recently decided the appeal from the first such proceeding. Declining to transfer, the District of Columbia Gircuit pointed out that "general familiarity with the legal questions presented by a case is decidedly different from acquaintance with the proceedings that gave rise to the order in suit." 183

These more recent cases indicate that the District of Columbia Circuit has abandoned the "familiar with the background of the controversy" test and adopted instead a narower standard, first articulated in Public Service Commission. Under this new test, a court should transfer only where "the same or inter-related proceeding was previously under review in a court of appeals, and is now brought for review of an order entered after remand, or in a follow-on phase, where continuance of the same appellate tribunal is necessary 'to maintain continuity in the total proceeding.' " 184

There appears to be little difference between the new District of Columbia Circuit standard and the "same or interrelated proceedings" test that has evolved in the "same order" cases previously discussed. ${ }^{185}$ At least in those circumstances in which the first order has not been the subject of a final judicial opinion, ${ }^{186}$ it is difficult to imagine a case in which two orders would not be the "same order" but would be subject to discretionary transfer on the basis of the similarity of the proceedings under the District of Columbia Circuit test. ${ }^{187}$ The test probably has its greatest appli-

183 Id. 857. The court relegated the Municipal Distributors case, see note 181 supra, to a footnote. 555 F.2d at 858 n.5.

The author believes that Public Service Commission and American Public Gas Association were rightly decided. The fact that one court has already decided a case involving similar factual or legal questions is no reason to transfer that case, regardless of the additional expertise that three judges of that circuit might possess. The complaint here is with the failure of the District of Columbia Circuit to overrule Municipal Distributors and limit Eastern Air Lines to its peculiar facts.

184 Public Serv. Comm'n v. FPC, 472 F.2d 1270, 1272 (D.C. Cir. 1972) (quoting Pacific Gas \& Elec. Co. v. FPC, 282 F.2d 510, 511 (D.C. Cir. 1958)).

185 See notes 137-46 supra \& accompanying text. The "same or interrelated proceeding" test that has evolved in the "same order" cases actually has its origin in Public Service Commission. The court in BASF Wyandotte Corp. v. Costle, 582 F.2d 108, 112 (1st Cir. 1978), quoted the Public Service Commission test for discretionary transfers as the test for deciding whether two or more orders are the "same order" for purposes of $\$ 2112(a)$. Hence, there should indeed be very little difference between the two tests.

186 See text accompanying note 145 supra.

187 The only relevant case is American Tel. \& Tel. Co. v. FCC, 519 F.2d 322 (2d Cir. 1975), in which the FCC denied an individual rate increase to AT\&T based on a previous order setting a general rate of return for that company. A petition for review of the prior order was pending in the District of Columbia Circuit. Declining to hold that the two orders were the "same order" under $\$ 2112$ (a), the Second Circuit nevertheless exercised its inherent power to transfer. The court, however, indicated that, if pressed, it would have held the two 
cation to cases in which a court receives the first petition for review of an order issued in a proceeding in which another court has already issued an opinion on another order in the same or similar proceeding. As previously noted, the courts have rarely, if ever, transferred under the "same order" provision of section 2112(a) in such a case. ${ }^{188}$ The District of Columbia Circuit rule should similarly guarantee that few cases will be transferred from that circuit to other circuits that have previously decided appeals from the same or related proceedings.

The other appellate courts have not rallied behind the narrow "same or interrelated proceedings" test espoused by the District of Columbia Circuit. ${ }^{189}$ Only the First Circuit has shown some interest in it. 190 The Third Circuit, on the other hand, has recently adopted a test that would appear to be more liberal toward transfer than even the "familiar with the background of the controversy" test. In United Steelworkers v. Marshall, ${ }^{191}$ petitions to review OSHA's lead standard were filed simultaneously in the Third and Fifth Circuits. Pursuant to an agreement between the judges of the two circuits, the Third Circuit agreed to determine which court should decide the merits of the controversy. Rather than accept jurisdiction or transfer to the Fifth Circuit, the court surprisingly transferred to the District of Columbia Circuit where no one had filed a petition for review. ${ }^{192}$ The court noted that a petition had

orders to be the "same order." The court stated that it viewed AT\&T's argument that the two orders were not the same "as unduly restrictive." Id. 325. The court pointed out that the proceedings were "closely related," and that the District of Columbia Circuit was "intimately familiar with the background" of the controversy. $I d .327$.

188 See text accompanying notes $145-49$ supra.

189 See, e.g., American Tel. \& Tel. Co. v. FCC, 519 F.2d 322 (2d Cir. 1975); Farah Mfg. Co. v. NLRB, 481 F.2d 1143 (8th Cir. 1973); note 179 supra.

190 The First Circuit cited the District of Columbia Circuit's "same or interrelated proceedings" test with approval in BASF Wyandotte v. Costle, 582 F.2d 108, 112 (1st Cir. 1978), in adopting that test for determining whether two successive orders were the same order. The First Circuit also cited the District of Columbia Circuit rule favorably in NLRB v. Bayside Enterprises, Inc., 514 F.2d $475,476 \mathrm{n} .{ }^{*}$ (Ist Cir. 1975), for the unrelated proposition that the circuit in which the first petition is filed should decide which circuit should hear the merits. Whether that circuit will adopt the same test for deciding whether to order a discretionary transfer remains to be seen.

191592 F.2d 693 ( $3 \mathrm{~d}$ Cir. 1979). For a detailed discussion of the case, see text accompanying notes $35-39$ supra.

192 Although the court did not address the question of its authority to transfer to another court in which no petition had been filed, $\$ 2112$ (a) probably gives it such authority. That statute allows transfer to "any other court of appeals." 28 U.S.C. $\$ 2112(a)$ (1976). Indeed, transfer is not even limited to courts in which venue is otherwise proper: "The breadth of language and vision of $\$ 2112$ goes beyond the precipitating evil [forum shopping by agencies], as is made clear by the final clause permitting transfer for reasons of sound judicial administration, 
been filed in that circuit to review a challenge to EPA's national ambient air quality standard for lead. Because both the EPA and OSHA proceedings addressed the health effects of human exposure to airborne lead, the court reasoned that there was "a strong institutional interest" in having those issues decided together in the District of Columbia Circuit.193 The court referred to the "desirability of concentrating litigation over closely related issues in the same forum so as to avoid duplication of judicial effort." 194

It seems clear that the Steelworkers case could not possibly have been transferred under the District of Columbia Circuit's "same or interrelated proceedings" test. The OSHA order was not an order entered on remand of the EPA order, nor was the OSHA order part of a "follow-on phase" of the EPA order "where continuance of the same appellate tribunal is necessary 'to maintain the continuity of the total proceeding." " 195 The two orders were issued in two entirely separate proceedings by two different agencies under two different statutes. The only similarity between the two is that they both resolved similar factual and policy questions concerning the health effects of airborne lead. Yet the answers to these questions could very well depend upon the language of the individual statutes. For example, the standard of review under the Clean Air Act is "arbitrary and capricious," 196 whereas the Occupational Safety and Health Act standard is "substantial evidence." 197 Although the Third Circuit cited judicial economy in support of its transfer, it is not at all clear that the same District of Columbia Circuit panel will hear both cases. According to the

notwithstanding objections, to a court which would not have had venue in the first instance." Eastern Air Lines, Inc. v. CAB, 354 F.2d 507, 511 (D.C. Cir. Cir. 1965).

193592 F.2d at 698. The court pointed out that the Clean Air Act's provision for exclusive review of national ambient air quality standards in the District of Columbia Circuit, 42 U.S.C.A. $\$ 7607$ (b)(1) (Supp. 1980), precluded that circuit from transferring to the circuit that heard the OSHA appeal.

104592 F.2d at 697.

195 Public Serv. Comm'n v. FPC, 472 F.2d 1270, 1272 (D.C. Cir. 1972) (quoting Pacific Gas \& Elec. Co. v. FPC, 282 F.2d 510, 511 (D.C. Cir. 1958)). 19042 U.S.C.A. $\$ 7607$ (d)(9) (Supp. 1980).

10729 U.S.C. $\$ 655$ (f) (1976). It has been persuasively argued that these two standards may not differ in practice when a court is reviewing a rulemaking record. See Industrial Union Dep't v. Hodgson, 499 F.2d 467 (D.C. Cir. 1974); Associated Indus. v. Department of Labor, 487 F.2d 342 (2d Cir. 1973); DeLong, supra note 42, at 287-89; Scalia \& Goodman, Procedural Aspects of the Consumer Product Safety Act, 20 U.C.I.A. L. Rev. 899, 934-35 (1973). However, other subtler differences between the statutes could affect a court's role, especially in reviewing an agency's resolution of what the author has in another context called "science policy questions." See McGarity, Substantive and Procedural Discretion in Administrative Resolution of Science Policy Questions: Regulating Carcinogens in EPA and OSHA, 67 GEo. L. J. 729, 792 (1979). 
court in Public Service Commission v. FPG, 198 the District of Columbia Circuit has adopted a system for the selection of judges that is based on a lottery. The only exception is "for retention of the same panel that handled an earlier appeal in the same case . . . but not for reference to a panel that handled a different case on the basis of similarity of underlying questions." 199 The Steelworkers facts would not appear to come within this exception.

While the Third Circuit has clearly drawn a broader transfer test than the "same or interrelated proceedings" test adopted by the District of Columbia Circuit for cases in which related proceedings are currently pending in another circuit, it is not clear that the Third Circuit will extend its broad Steelworkers approach to cases in which another circuit has already decided a similar or related case. The court indicated that it would not have transferred to the District of Columbia Circuit if the EPA case had already been decided when it rejected judicial expertise as a transfer criterion and stated that "it would be improper to speculate that any circuit court of appeals is more expert in OSHA matters than another." 200 For the present, it is not clear which view will ultimately prevail. The Supreme Court has never examined a section 2112(a) case, and because those cases all involve preliminary skirmishes over which circuit shall hear a case, that Court is not likely to further delay the determination of the threshold question by granting certiorari in such a case.

\section{F. Temporary Stays}

The nature of many kinds of administrative action is such that initial steps toward compliance cannot easily be undone if a court ultimately overturns the agency's action. Hence, petitioners often ask courts to stay temporarily the effectiveness of administrative orders pending appeal. In cases involving races to the courthouse, a party occasionally must request a stay before the outcome of the race is determined, and it is not uncommon for a court to issue a stay before deciding whether to transfer the proceedings to another circuit. ${ }^{201}$ This poses many still unanswered questions concerning the jurisdiction of the transferring court to enforce the stay after

198472 F.2d 1270 (D.C. Cir. 1972).

199 Id. 1273.

200 United Steelworkers v. Marshall, 592 F.2d 693, 697 (3d Cir. 1979).

201 See Industrial Union Dep't v. Bingham, 570 F.2d 965 (D.C. Cir. 1977); American Pub. Gas Ass'n v. FPC, 555 F.2d 842 (D.C. Cir. 1976); Bristol Laboratories, Inc. v. Richardson, 456 F.2d 563 (Ist Cir. 1971); Valley Vision, Inc. v. FCC, 383 F.2d 218 (D.C. Cir. 1967). 
transfer and the ability of the transferee court to lift the transferring court's stay. Both dilemmas strain judicial comity. ${ }^{202}$ For example, in Industrial Union Department v. Bingham ${ }^{203}$ the Fifth Circuit issued a temporary stay of OSHA's temporary emergency benzene standard on May 20, 1977, and set a date of June 6, 1977, for a hearing to determine whether the stay should be continued for the duration of the litigation. The union believed that it had filed the first petition for review in the District of Columbia Circuit, and it therefore urged the Fifth Circuit to lift the stay and transfer immediately to the District of Columbia Circuit. When the Fifth Circuit failed to do this, the union asked the District of Columbia Circuit for an emergency ex parte restraining order to prevent the Fifth Circuit petitioners from implementing the orders of the Fifth Circuit or in the alternative to dismiss their case in that circuit. The District of Columbia Circuit avoided this direct threat to judicial comity by denying the motion. Unfortunately, the court did not publish an opinion giving its reasons for doing so. ${ }^{204}$

Perhaps because of the threat to judicial comity, no transferee court has lifted a transferring court's stay. Petitioners therefore have an additional incentive to forum shop for temporary stays. Even if a petitioner loses the race, it can still request the court of its choice to stay the administrative order pending appeal, and it can be reasonably confident that the stay will last until some court decides the merits of the controversy.

\section{G. Simultaneous Filings}

As the races to the courthouse have intensified it has become increasingly difficult for the courts of appeals to pick the winners. Although some courts still insist upon having a winner, even if that requires findings accurate to the hundredth of a second, ${ }^{205}$ other courts have recognized the artificiality of such findings and have proceeded on the assumption that two petitions filed within seconds

202 See notes 50-58 supra \& accompanying text.

203570 F.2d 965, 974 n.4 (D.C. Cir. 1977) (opinion of Wilkey, J.).

204 See also Valley Vision, Inc. v. FCC, 383 F.2d 218 (D.C. Cir. 1967), in which the District of Columbia Circuit, in order to preserve judicial comity, transferred a proceeding to the Ninth Circuit (which had already issued a stay), despite the former circuit's conviction that it had exclusive jurisdiction over all petitions to review the type of FCC order under challenge.

205 See text accompanying notes 97-103 supra. See also Southland Mower Co. v. CPSC, 600 F.2d 12 (5th Cir. 1979); Shell Oil Co. v. FPC, 509 F.2d 176, 179 (D.C. Cir. 1975). 
of one another are in fact simultaneous filings. ${ }^{206}$ Recent administrative regulations that set a particular time in the future at which agency orders become ripe for judicial review ${ }^{207}$ should eliminate races and ensure that petitions are filed in different courts within milliseconds of one another, thus frustrating even further the strict adherents to the first-to-file rule. ${ }^{208}$ Yet as the first-to-file rule has been abandoned in tight races, new problems have surfaced in the practice under section 2112(a).

When faced with virtually simultaneous filings, those courts that do not insist upon declaring a winner have proceeded directly to the question of discretionary transfer. ${ }^{209}$ This solution, however, does not solve the threshold problem of determining which court shall decide the discretionary transfer question. The courts have apparently adopted the practice, first announced in American Public Gas Association v. FPC, ${ }^{210}$ of resolving this question through informal telephone conversations between the judges of the circuits. The advantage of this approach is its speed and efficiency. The disadvantage is its secrecy. The judges decide upon the circuit that will decide the discretionary transfer question without the benefit of briefs or oral arguments; they have no announced criteria to guide their discretion; and they do not have to justify the result. On the other hand, because the process only determines which court shall determine the proper court to decide the merits, this may well be one of those trivial areas where the importance of the issue cannot justify greater procedural formality.

206 See United Steelworkers v. Marshall, 592 F.2d 693 (3d Cir. 1979); American Pub. Gas Ass'n v. FPC, 555 F.2d 852 (D.C. Cir. 1976); Municipal Distribs. Group v. FPC, 459 F.2d 1369 (D.C. Cir. 1972); International Union of Elec., Radio \& Mach. Workers v. NLRB, 343 F.2d 327 (D.C. Cir. 1965).

207 See note 17, supra.

208 Interestingly, in the only case in which there has been a race under the recent agency "race-to-the-courthouse" designations the court still insisted that a winner be picked. In Southland Mower Co. v. CPSC, 600 F.2d 12 (5th Cir. 1979), the Fifth Circuit upheld the Consumer Product Safety Commission's determination that its order would be ripe for judicial review at 12:00 noon, Eastern Standard Time, on February 26, 1979. The court, however, found that the Fifth Circuit petitioner filed approximately one minute prior to the District of Columbia Circuit petitioner.

EPA has suggested that races may still be possible under its "race-to-thecourthouse" regulations if racers utilized "atomic chronometers synchronized to the clock at Greenwich." Final EPA Race Regulations, supra note 17, at 26,407.

209 United Steelworkers v. Marshall, 592 F.2d 693 (3d Cir. 1979); American Pub. Gas Ass'n v. FPC, 555 F.2d 852 (D.C. Cir. 1976); Municipal Distribs. Group v. FPC, 459 F.2d 1367 (D.C. Cir. 1972). But cf. International Union of Elec., Radio \& Mach. Workers v. NLRB, 343 F.2d 327 (D.C. Cir. 1965) (one of two simultaneous petitions transferred to Second Circuit because NLRB planned to petition for enforcement of the contested orders in that circuit).

210555 F.2d 852, 861 app. C (D.C. Cir. 1976). See United Steelworkers v. Marshall, 592 F.2d 693, 695 (3d Cir. 1979). 
In any event, recent judicial experience with simultaneous filings does suggest the need for establishing some agreed-upon mechanism for deciding which court shall identify the court that will decide the merits of the controversy.

\section{SUGGESTIONS FOR REFORM}

\section{A. The Need for Reform}

The preceding analysis of current practices under section 2112 (a) reveals several strengths and weaknesses of the first-to-file rule. The rule has succeeded reasonably well at preserving judicial comity ${ }^{211}$-the courts have been faithful to the rule, and one court has even transferred to the court of first filing despite its conviction that it had exclusive jurisdiction. ${ }^{212}$ Yet while strict adherence to the mechanical rule has in the past avoided unseemly judicial conflicts, the recent spate of simultaneous filings may resurrect that possibility in the future. The informal conference mechanism may break down as more agencies promulgate race-tothe-courthouse rules and thereby guarantee more numerous simultaneous filings in several circuits.

Section 2112(a) also retains the percolation and signaling ${ }^{213}$ advantages of forum shopping. Even though the agency cannot shop, a sympathetic, but aggrieved public interest group can still win the race to a "friendly" court. Indeed, several of the important recent Supreme Court decisions in the environmental and occupational safety and health fields would probably not have been decided but for intercircuit disputes that signaled the Court of the need to grant certiorari. ${ }^{214}$ However, the recent Third Circuit practice of ordering discretionary transfer of cases to circuits that are deciding "closely related" questions 215 may, if followed by other circuits, reduce this advantage somewhat.

These advantages of the current first-to-file mechanism do not come without great costs. Section 2112(a) exacerbates the adverse effects that forum shopping can have on the public image of lawyears and courts. ${ }^{216}$ The thought that lawyers sometimes base

211 See notes 50-58 supra \& accompanying text. 59 supra.

212 Valley Vision, Inc. v. FCC, 383 F.2d 218 (D.C. Cir. 1967). But see note

213 See notes 78-82 supra \& accompanying text.

214 See note 67 supra.

215 See notes 191-99 supra \& accompanying text.

216 See note 49 supra \& accompanying text. 
their choice of forums on their assessments of the pre-existing judicial biases ${ }^{217}$ and the sight of attorneys scrambling madly to implement their choices might tarnish the carefully cultivated image of the bar and subject its members to public ridicule.

The apparent inability of some agencies to initiate a fair race with an agreed-upon starting point can likewise undermine the integrity of the administrative and judicial review process. While the agencies can justifiably bear some of the blame for unequal races, ${ }^{218}$ much of the apparent unfairness of agency and court attempts to implement section 2112 (a) is attributable to basic incompatibilities between the administrative process and the race concept. Many aspects of the administrative process are openended. A single proceeding can sire many orders, all of which may be ripe for appeal, but none of which may be a firm end-point from which a definitive race can be clocked. While it may seem unfair for the petitioner that challenged EPA's final regulation in BASF Wyandotte Corp. v. Costle ${ }^{219}$ to learn that the race it had recently completed had ended two years previously, it does violence to the continuous character of the administrative process to insist, as that petitioner did, that EPA's interim rules were so unrelated to its final rules that review in different courts was warranted. In reality, both sets of rules were part of a continuing evaluation, prescribed by statute, of EPA's technology-based standards for the pesticides industry. This process began in 1974 when EPA was ordered by a court to promulgate "best practicable technology" effluent limitations for the pesticides industry, ${ }^{220}$ and it will not end until 1981 or later when EPA promulgates final "best available technology economically achievable" regulations for that industry. This is not to say that there are not interim steps along the way at which EPA's actions are properly subject to judicial scrutiny; it does, however, suggest that the potential for unfairness and absurdity is high in a forum selection process that presumes that the administrative process yields discrete units of reviewable information.

Because it allows private petitioners to forum shop, section 2112(a) does nothing to discourage the threat that forum shopping

217 See notes 41-42 supra \& accompanying text.

218 OSHA surely must take the blame for the badly bungled race in Industrial Union Dep't v. Bingham, 570 F.2d 965 (D.C. Cir. 1977). See text accompanying notes 20-34 and 115-19 supra. text.

219582 F.2d 108 (1st Cir. 1979). See notes 139-44 supra \& accompanying

220 Natural Resources Defense Council, Inc. v. Train, 396 F. Supp. 1393 (D.D.C. 1975). 
poses to the uniform application of administrative legal and policy decisions. ${ }^{221}$ Congress enacted section 2112(a) with an eye towards checking the NLRB's perceived attempts at shopping for a favorable forum for review of its unfair labor practice determinations. ${ }^{222}$ National standard setting was not involved, and hence no particular need for uniformity existed. Yet the punishment meted out to the NLRB continues to plague the national standard-setting processes of agencies that did not even exist when the NLRB committed its alleged transgressions. While section 2112 (a) may not leave the courts powerless to consider, in ordering or refusing discretionary transfer, the effects that an adverse ruling from the transferee court might have on the agency's attempt to implement a national program, no court has yet explicitly listed this as a factor in its deliberations. ${ }^{223}$ Fortunately, the courts have at least refused to encourage regionalistic attacks on national uniformity by declining to consider which region might be most affected in ordering discretionary transfer. ${ }^{224}$

For the same reasons that section 2112(a) fails to encourage the uniform implementation of national programs, that section does little to reduce the business uncertainty that forum shopping can cause. $^{225}$ For issues on which the entire business world is united in its opposition to an agency's position, section 2112(a) does increase business certainty by preventing the agency from forum shopping. However, this aspect of section 2112(a) has limited value in regulatory areas, such as route allocations, that involve interbusiness rivalry or in cases in which public interest groups take the position that the agency has not done enough to protect their interests.

While one can imagine more expensive ways to channel forum shopping, section 2112(a)'s race-to-the-courthouse approach does not come cheaply.226 The races themselves can be quite expensive. The greatest cost, however, is in the resources expended in threshold litigation over the timing of the starting gun, the outcome of the race, the scope a single or successive orders under the "same order" provision, and the advisability of discretionary transfer. Hundreds of hours of attorney and court time have been wasted in

221 See notes 60-73 supra \& accompanying text.

222 See Comment, Forum-Shopping in the Review of NLRB Orders, $28 \mathrm{U}$. Car. L. REv. 552, 557 n.25 (1961).

223 One court has spoken, however, of "the need for continuity and consistency in reviewing a series of agency decisions." Abourezk v. FPC, 513 F.2d 504, 505 n.1 (D.C. Cir. 1975).

224 See note 161 supra \& accompanying text.

225 See notes 74-75 supra \& accompanying text.

226 See notes 76-77 and 104-06 supra \& accompanying text. 
threshold litigation with no conceivable corresponding benefits to society.

In sum, while section 2112(a) has retained the chief advantages of forum shopping, it has exacerabated many of its disadvantages. Moreover, that section has spawned a whole body of threshold litigation that did not exist prior to its enactment. Reform therefore seems advisable. Indeed, the trend toward promulgating race-tothe-courthouse regulations may make reform inevitable. However, in assessing proposals for reform, one must not lose sight of the magnitude of the problem. Forum shopping under section 2112(a) is not a legal problem of such major significance that it alone can justify large-scale tinkering with the currently existing system for judicial review of administrative action. Fortunately, less ambitious reforms can eliminate or greatly reduce most of the disadvantages of forum shopping while retaining most of the advantages.

\section{B. Patch and Repair}

Before advocating wholesale institutional change, or even minor statutory reform, one ought to explore possible corrective actions within the present judicial and administrative framework of section 2112(a). This section of the Article examines several available reforms and assesses the likelihood that they can be successfully implemented. It concludes that several possible administrative reforms can offer some improvement in the current section 2112(a) practice and that these reforms can be implemented rather easily. Reforms on a scale necessary to improve significantly the forum shopping problem, however, must await congressional action.

\section{Judicial Patch and Repair}

\section{a. Penalties for Racing}

While section 2112(a) does not discourage races, the courts could easily do so by consistently ordering discretionary transfer to the circuit of the later-filed petition whenever they suspect that the first-filed petition was the result of a race. This easily imposed judicial remedy could reduce or eliminate many of the disadvantages of forum shopping while preserving the system's capacity for "percolation" and for signaling the Supreme Court. Moreover, such transfer might be justified as "in the interest of justice." 
While penalizing racers seems to be, at first glance, an attractive technique for remedying section 2112(a)'s weaknesses, it has several failings. First, it runs directly contrary to Congress's resolution of the forum shopping problem. Congress clearly saw the discretionary transfer provision of section 2112(a) as an exception to the firstto-file rule, not as an alternative mechanism that would one day supplant the rule entirely. Courts that transferred every petition resulting from a race would be effectively writing the first-to-file rule out of the statute. 227 It is also questionable whether the "in the interest of justice" rationale would support the penalizing of all racers. A relatively inexpensive race conducted in an unobtrusive manner between parties equally able to afford the cost is unjust to no private party, and has little harmful impact on society as a whole.

The most significant infirmity of the penalty approach, however, is that it probably would not work. Automatic transfer of petitions that appeared to result from races would change the nature of the races, but it would not eliminate them. Racers would have to stop filing petitions prior to reading the agency's rationale for its order, but because section 2112(a) would still reward the first bona fide filer, the race would proceed in a subtler fashion. The race might thus more closely resemble a rally than a drag race.

The second infirmity suggests a third. The courts would invariably be called upon to decide what is, and is not, a race. Resolving whether a petitioner has raced might be more difficult than deciding whether he or she has won, because it inevitably invites a probe into the alleged racer's motives. Thus, while penalizing racers might enhance the decorum of the race and save clients the expense of the sprint, it would not reduce the agency, client and court resources needed to find the proper resting place for a case, and it might even increase those costs.

Finally, penalizing racers would only act as a disincentive if penalties were uniformly and consistently applied. If one court consistently declined to transfer, forum shoppers could still race to that circuit. The courts have in the past been unwilling to penalize racers, and there is little chance that they will begin to do so absent a statutory mandate. Hence, the necessary consistency will probably not evolve without congressional action.

$22 \pi$ A similar argument could be made if a court were to rely upon its common law inherent power to transfer, see text accompanying note 151 supra, instead of $\S 2112$ (a)'s discretionary transfer provision. Such judicial action which rendered a constitutionally valid congressional statute a nullity would probably exceed the bounds of judicial discretion. 


\section{b. Uniform Judicial Adherence to the Doctrine of Controlling Decision}

The courts could eliminate much forum shopping by eliminating the perception in lawyers' minds that it pays to shop. Professor Vestal has recently suggested that forum shopping and many other evils could be reduced or eliminated if the courts of appeals would return to their previous adherence to the "doctrine of controlling decision." 228 That doctrine holds that "as a matter of judicial comity a court should follow a decision of a court of coordinate jurisdiction on a question of law." 229 If the courts of appeals strictly adhered to this doctrine, an unfavorable legal precedent in one circuit would theoretically create no incentive to avoid that circuit in future cases, because the court that heard the second case would be bound by the first decision.

Assuming that the courts of appeals agreed in principle to abide by the doctrine of controlling decision, their action would probably have very little impact on forum shopping. The doctrine on its face applies only to questions of law. It would therefore encompass only appeals based upon the agency's statutory construction and perhaps upon the validity of the agency's procedural choices; it would have no impact at all on forum shopping for review of the record support for an agency's decision. A more serious objection is that the proposal addresses only such forum shopping as occurs after one court has rendered a decision on a legal question. Rather than discouraging forum shopping, the proposal might encourage the parties to pursue even more vigorously forum shopping for the circuit to decide the first case, because the stakes would be much higher. The controlling decision doctrine, if thoroughly implemented, would also eliminate forum shopping's "percolation" and signaling advantages.

The courts of appeals have shown no great respect for the doctrine of controlling decision in recent years. Professor Vestal's painstaking and comprehensive analysis of that doctrine in the eleven circuits is elegant testimony to the refusal of today's

228 See Vestal, supra note 44, at 165 . Professor Vestal recommends that the courts preclude federal agencies from relitigating legal issues that have already been decided by one circuit court. As already discussed, see text accompanying note 62 supra, this solution would be inadequate for the large number of administrative "polycentric" proceedings in which appeals may be filed by parties that are aggrieved but are in substantial agreement with the agency. This Article assumes, therefore, that the doctrine of controlling decision would apply to all parties to an administrative appeal. 
independent-minded appellate courts to adhere to it. ${ }^{230}$ Indeed, even panels within individual circuits do not necessarily adhere to the doctrine as applied to prior decisions of other panels in the same circuit. ${ }^{231}$ Judicial performance therefore leads Professor Vestal to the somewhat understated conclusion that "the doctrine of controlling decision may not have the vitality it once had." 232 The courts of appeals are not likely to rally round that doctrine in the near future. Even if the doctrine were somehow imposed upon them through statute or Supreme Court decision, cases are easily enough distinguished from one another that independent panels could still avoid thorough application of the doctrine, and forum shoppers would still race.

Perhaps sensing judicial reluctance to implement the doctrine of controlling decision, another commentator has suggested statutory imposition of stare decisis upon the courts of appeals as a mechanism for securing national uniformity. ${ }^{233}$ Under this proposal an en banc holding by one circuit on a question of law would be binding upon all panels of all other circuits. ${ }^{23}$ A subsequent court of appeals, sitting en banc, could write an opinion stating its objections to the former circuit's reasoning, but it could not reverse that circuit. ${ }^{235}$ The dissenting opinion would act as a signal to the Supreme Court that the two circuits disagreed, and it could provide some degree of percolation.

Except for adding the percolation and signaling functions, however, this proposal retains all of the disadvantages of the controlling decision doctrine. It only discourages forum shopping for forum avoidance; the forum for the first decision becomes even more important. Parties could still forum shop for review of the record support of agency action. Finally, a court of appeals that desired to avoid the statutory rule could do so easily enough by distinguishing undistinguishable cases.

\section{c. More Frequent Supreme Court Review of Intercircuit Conflicts}

It has been suggested that much of the added burden on the courts of appeals that is due to intercircuit forum shopping is attributable to the Supreme Court's failure to review administrative

230 Id. $140-60$.

281 See id. 161; Wasby, supra note 44.

232 Vestal, supra note 44, at 166.

233 Note, supra note 81.

234 Id. 1239.

235 Id. 1240. 
action with sufficient regularity. ${ }^{236}$ If litigants were assured of a high probability that their appeals would ultimately be heard in the Supreme Court, then the incentive to shop among the intermediate courts might be reduced. The Supreme Court might therefore be urged to exercise greater supervision over the lower courts to eliminate the divergencies in approach that breed forum shopping.

The premise of this proposal, however, is open to challenge. It is not universally true that the Court has been slow to review administrative appeals. Supreme Court review of legal questions in the environmental and occupational health and safety fields, for example, has been reasonably frequent..237 Indeed, the Court's good record in reviewing intercircuit conflicts provides the parties with an incentive to forum shop to avoid a prior precedent, as is evidenced by the recent spate of forum avoidance attempts in those fields. Unless the Supreme Court dramatically increased the number of administrative appeals that it reviewed at the expense of other appeals involving important national issues, the possibility of Supreme Court review would have little effect on such forum shopping as is based on the general reputations of the circuits.

\section{d. Simultaneous Filings}

Although broad-scale attempts at judicial solutions to the forum shopping problem are probably not warranted, the courts can address the thorny problem of simultaneous filings that is beginning to imperil the workability of the first-to-file rule. ${ }^{238}$ The courts could attempt to remedy the problem of simultaneous filings in a variety of ways. They could, for example, establish an ad hoc panel of judges from the circuits in which petitions have been filed to pass upon the discretionary transfer question. This solution, however, would merely establish a second threshold level of argument that would seem to be particularly wasteful.

A better solution would be for the courts, through the Judicial Conference, to adopt an automatic mechanism, such as a lottery,

236 Id. 1223. See also Hruska Commission Report, supra note 41, at 221-24, 298-99; Leventhal, supra note 19, at 888; Note, supra note 81 , at 1223. But see G. Casper \& R. Posner, The Workload of the Supreme Court 91 (1978).

237 See note 67 supra. The survey of agency general counsels conducted by Professors Currie and Goodman for the Hruska Commission revealed very little dissatisfaction with the Supreme Court's record in resolving intercircuit conflicts. See G. CASPER \& R. POSNER, supra note 236, at 91; Hruska Commission Report, supra note 41 , at $376-90$.

238 See notes 205-10 supra \& accompanying text. 
for deciding which court will make the threshold determination. In cases in which two or more petitions are filed within less than a specified fraction of a minute of one another, ${ }^{239}$ the clerks of all courts in which petitions were filed would be required to telephone the Administrative Office of the United States Courts and apprise it of that fact. The Administrative Office could then choose the circuit to hear the threshold arguments by lot. Although there is no explicit statutory authority for this proposed solution to the simultaneous filings impasse, an arguable case can be made that the courts have authority to adopt such a mechanism under their general housekeeping statute. ${ }^{240}$ Still, to the extent that this judicially imposed solution is inconsistent with the first-to-file rule of section 2112 (a), its validity is in doubt.241 Ultimately, Congress has the responsibility to repair section 2112(a)'s failed mechanism.

\section{Agency Patch and Repair}

Reacting to an anticipated flood of future courthouse races, ${ }^{242}$ the agencies have already begun to patch the crumbling section 2112(a) edifice. ${ }^{243}$ Two agencies have recently promulgated race-tothe-courthouse regulations that directly address the problems raised by such races, and the courts have so far viewed the regulations favorably.244 These regulations are designed to ensure that the race is run fairly and that all parties know the precise moment at which the race begins. By setting the time for the race sufficiently far in advance these regulations also eliminate the spectacle and expense of past races. Attorneys may with the utmost decorum study the agency's regulation, write reasonably comprehensive petitions for review, and file those petitions in the forum of choice at precisely the moment that the race begins. These recent regulations

239 The specified fraction should depend on the accuracy of courthouse clocks. Fifteen seconds is probably a good estimate of the ability of courthouse clocks to record simultaneous events.

240 Congress has given the federal courts the general authority to "from time to time prescribe rules for the conduct of their business." 28 U.S.C. $\$ 2071$ (1976). See generally 4 Wright \& MrL.ER, supra note 4, at $\$ 1001$; Weinstein, Reform of Federal Court Rulemaking Procedures, 76 CouUn. L. REv. 905 (1976).

241 The federal housekeeping statute, 28 U.S.C. \$2071 (1976), explicitly exempts from its delegation of rulemaking authority exercises of that authority that would be inconsistent with acts of Congress.

242 See Judicial Review Under Clean Water Act; Races to the Courthouse, Proposed Rule, 44 Fed. Reg. 32,006, 32,007 (1979).

243 Agency efforts to address courthouse races have received the encouragement of the courts. See Industrial Union Dep't v. Bingham, 570 F.2d 965, 970 (D.C. Cir. 1977) (opinion of Leventhal, J.).

244 See note 17 supra. 
are exemplary attempts to remedy past deficiencies and, in the absence of further legislation, other agencies should be encouraged to adopt similar race-to-the-courthouse regulations.

The agencies can, however, do even more to alleviate problems that have arisen under section 2112(a). The agencies could significantly aid the courts in resolving questions concerning the scope of agency orders ${ }^{245}$ and the status of successive orders ${ }^{246}$ by addressing these questions prior to appeal. For example, when an agency simultaneously issues what looks like several orders at the end of a single proceeding, as in Bristol Laboratories, Inc. v. Richardson, ${ }^{247}$ the agency could simply state at the outset that it considered all of the orders the "same order" for purposes of section 2112(a). Similarly, when an agency in a continuing proceeding issues a successive order before the appeal of a prior order from the same proceeding has been decided, the agency could at the time it issues the second order state its determination that they are both the "same order."

One serious objection to this proposal is that critics could charge the agency with attempting to usurp the courts' power to interpret section 2112(a). An initial agency assessment, however, would not purport to bind the reviewing courts; it would merely be an attempt to aid the courts in resolving a difficult threshold question. The courts would presumably give some deference to those initial agency determinations, because the agencies are familiar with their own statutes and their unique procedural peculiarities. In upholding the CPSC and EPA race-to-the-courthouse requirements, both the Fourth and Fifth Circuits stressed that "[a]gencies have a great deal of discretion in determining the manner in which their actions are promulgated." 248 The courts should show similar deference to agency attempts to define the scope of their orders.

Another objection to this proposal is that, in the case of successive orders, agencies may use their power to determine the scope of facially separate orders as a means of forum shopping in derogation of the clear intent of section 2112(a) that they not be allowed to do so. If the agency were pleased with the circuit reviewing the first order, it could mark successive orders the "same order" as the first so that they too would be reviewed by that circuit. If, however, the agency were unhappy with the forum for review, it could call successive actions separate orders in the hopes that a non-adverse

245 See notes 129-36 supra \& accompanying text.

246 See notes 137-49 supra \& accompanying text.

247456 F.2d 563 (Ist Cir. 197I).

248 Virginia Elec. \& Power Co. v. EPA, 610 F.2d 187, 188 (4th Cir. 1979) (quoting Southland Mower Co. v. CPSC, 600 F.2d 12, 13 (5th Cir. 1979)). 
party will this time win any ensuing race. The incentive to forum shop in this manner, however, is not very strong. The agency would know which court was deciding the first appeal, but it would not know how that court decided. ${ }^{249}$ There may be a temptation here for the agency to take that court's general reputation into account in making its "same order" determination, but it should not be very strong in light of the convenience to the agency itself of arguing both appeals at the same time in the same place. Moreover, the agency should have some incentive to resist that temptation in order to maintain consistency in making "same order" determinations through time. Finally, judicial review of the "same order" determination, though deferential, should be capable of curing agency abuses. In sum, agency "same order" determinations could substantially aid the threshold process in the few cases that call for that determination without much risk of doing violence to the intent of section 2112(a).

\section{Statutory Reforms}

Because agency and judicial patch and repair efforts are not likely to remedy many of the problems that have arisen in the section 2112(a) practice, statutory changes should be considered. In considering statutory changes, however, one should bear in mind that the current section 2112(a) practice, while nettlesome and professionally embarrassing, is not a major social problem. Proposals for statutory reform must reflect the modest nature of the problem that they address.

Proposals for statutory reform could attempt either to eliminate forum shopping entirely, or merely to manage it by eliminating some of its more unseemly and wasteful aspects. It is difficult, however, to envision a reasonably workable scheme for eliminating forum shopping outright that does not simply designate a single court of appeals to hear all administrative appeals of a certain type. Even the most careful delineation of the kinds of cases for which a particular court had exclusive venue would probably still breed threshold litigation; moreover, this would generally require Congress to choose sides in controversies over which court ought to have exclusive venue. Proposals for managing or controlling forum shopping are probably more politically palatable, but they leave

249 If the appeal of the first order has been decided, then the first and second orders can not as a matter of judicial fiat be considered the "same order." See notes 145-49 supra \& accompanying text. 
the underlying problem unresolved and therefore require constant vigilance to guard against predictable efforts to avoid the control mechanisms.

The following section of this Article examines and evaluates several proposals for eliminating or controlling forum shopping. It concludes that no acceptable mechanism for eliminating forum shopping is presently available. Of the control mechanisms an automatic mechanism seems preferable to proposed discretionary mechanisms.

\section{Mechanisms for Eliminating Forum Shopping}

\section{a. Exclusive Venue in a Particular Court}

Perhaps the most effective way to eliminate forum shopping is to limit the available forums to a single court. This could be accomplished either by designating one of the existing courts of appeals as the exclusive forum for some or all administrative appeals or by creating a new "administrative court." 250 Designating a single court to hear all appeals of a particular variety eliminates the cost and embarrassment of the race to the courthouse and much of the cost of litigating threshold matters. By allowing simultaneously pending cases involving the same or very similar legal and factual questions to be consolidated for argument before the same panel of that court, the proposal could even further increase judicial economy. Because only one court would have jurisdiction to hear particular appeals, there would likewise be no threat to judicial comity. Moreover, to the extent that panels within the single court would maintain consistency, this solution should reduce business uncertainty ${ }^{251}$ and encourage uniform application of national policy. ${ }^{252}$ Exclusive venue in a particular circuit is especially appropriate for programs for which Congress has imposed deadlines upon the agency and the regulated industry, because the uncertainty and delay attributable to conflicting court decisions that

250 This is by no means the first attempt to analyze the arguments for and against designating an exclusive forum for judicial review of administrative action. The author has relied heavily on the following sources: P. Carrungron, D. MEador, \& M. RosenberG, Justice on APpEAL (1976) [hereinafter cited as Justice oN Appeal]; Commisston on Revision of the Federal Court Appellate System, Hearings Second Phase 1974-1975, at 357 (1974) (testimony of A. Scalia) [hereinafter cited as Commisston on Revision]; GeNeral VIEw, supra note 81; Carrington, supra note 74; Currie \& Goodman, supra note 3; Leventhal, supra note 19; Nathanson, The Administrative Court Proposal, 57 V.A. L. REv. 996 (1971).

251 See Leventhal, supra note 19, at 884.

252 See General VIEw, supta note 81, at 186; Currie \& Goodman, supra note 3, at 63; Nathanson, supra note 250, at 1010; Vestal, supra note 44, at 176. 
result from forum shopping can frustrate such deadlines. An added advantage of exclusive review, unrelated to its effects on forum shopping, is the possibility that it would relieve the rest of the courts of appeals from some of their burdensome caseloads. ${ }^{253}$

On the other hand, vesting exclusive jurisdiction in a single court would completely deny the Supreme Court the percolating and signaling advantages of multi-circuit review. ${ }^{254}$ To the limited extent that convenience to the parties is a realistic concern, ${ }^{255}$ exclusive jurisdiction in a single court could cause inconvenience to some parties. ${ }^{256}$ Moreover, while vesting exclusive jurisdiction may take pressure off some courts, it will of course add to the pressure of the courts receiving exclusive jurisdiction. ${ }^{257}$ Even if a new "administrative court" is created to hear all administrative appeals, its caseload could easily match the current caseload of the District of Columbia Circuit.258 Still another danger of vesting exclusive review in a single court is the possibility that over time the relationship between the two institutions would either blossom

253 See CoMamisston on Revision, supta note 250, at 359; Genkrax VIEW, supra note 81, at 184; Currie \& Goodman, supra note 3, at 64; Nathanson, supra note 250, at 996 . There is, however, some debate as to just how much this would free up the appellate courts. Clearly, designating particular courts of appeals as exclusive courts to hear particular administrative appeals would reduce the load on the courts as a whole only to the extent that forum shopping presently accounts for additional cases. Even if an entirely new "administrative court" were created, the net reduction in the workload of the courts of appeals would apparently be of little significance. See Comanssion on Revrsion, supra note 250, at 359 (estimating nine percent reduction in federal appellate caseload); Currie \& Goodman, supra note 3 , at 64 ; Nathanson, supra note 250, at 997. Assuming that 1,400 cases of nationwide scope or effect in 1979 might have been shifted into an "adminisrative court," see text accompanying notes 265-67 infra, the administrative court in 1979 would only reduce the total workload of the appellate courts by approximately seven percent of its current 20,219 petitions. ADMTMSTrAtrve Office of the United States Counts, 1979 annual Report of the Director 44, table 2 [hereinafter cited as AO REPORT]. Indeed, even shifting all of the 2,922 appeals from administrative agencies would only reduce the workload by 14 percent.

254 See Currie \& Goodman, supra note 3, at 69; Note, Forum Shopping in Appellate Review of FTC Cease and Desist Orders, 13 UTAR L. Rev. 316, 338 (1968).

255 See text accompanying notes 156-58 supra.

256 See Carrington, supra note 74, at 605 ; Currie \& Goodman, supra note 3 , at 74 ; Note, supra note 254 , at 337.

257 See Justice on APPEAL, supra note 250, at 171; Carrington, supra note 74, at 605; Currie \& Goodman, supra note 3 , at 64 .

258 In fiscal $1979,1,415$ petitions were filed in the District of Columbia Circuit. AO REPORT, supra note 253 , at 44 , table 2. An estimated 1,000 to 1,400 cases would be heard by a court hearing only appeals from agency actions having nationwide scope of effect. See text accompanying notes 265-67 infra. If the "administrative court" heard all 2,922 agency appeals, AO REPORT, supra note 253, at 49 , table 6 , its caseload would be exceeded only by that of the Fifth Circuit. AO Repont, supra note 253, at 44, table 2. (The Ninth Circuit had 3,010 filings, but 471 of those were agency appeals, which would have gone to the "administrative court."). 
or sour to such an extent that the court would be either too hesitant or too eager to reverse agency decisions. ${ }^{259}$ In either case, the nature of judicial review of administrative action might change if a substantial number of administrative appeals were heard in a single circuit. Moreover, vesting exclusive venue in a single court for preenforcement review of major regulations would leave unanswered the question whether district courts and other appellate courts could reconsider the validity of the regulation at the enforcement stage. If the validity of regulations is open for review at the enforcement stage, the potential still exists for conflicting decisions despite the attempt to achieve uniformity through exclusive venue. ${ }^{260}$

Perhaps the greatest disadvantage of vesting a single court with exclusive jurisdiction over some or all administrative appeals is the difficulty of defining that court's jurisdiction accurately enough to preclude wasteful threshold litigation over jurisdictional matters. ${ }^{261}$ At one extreme Congress could amend the venue provisions of every statute that currently provides for court of appeals review of administrative action to specify a particular circuit for each agency action. While this approach should eliminate any threshold jurisdictional litigation, it would be extraordinarily cumbersome, and would undoubtedly touch off numerous congressional disputes over which courts should have exclusive jurisdiction over which appeals. Congress could, alternatively, draft a statute that would provide for exclusive venue in a single court for all administrative appeals over which federal courts of appeals have jurisdiction. This approach, however, would burden a single court with hundreds of appeals, such as from NLRB unfair labor practice findings, that have minimal, if any, national significance, and could force local litigants to argue their appeals in distant forums.

259 Compare Fels, supra note 85, at 46 and Nathanson, supra note 250 , at 1012-14 with Currie \& Goodman, supra note 3 , at 71 .

260 Congress could attempt to resolve the problem of review at the enforcement stage in one of two ways. First, Congress could simply prohibit such review, as it has done in the Clean Air Act, which precludes review in enforcement proceedings of actions with respect to which pre-enforcement review could have been obtained. 42 U.S.C.A. $\$ 7607$ (b) (2) (Supp. 1980). This solution, however, might be viewed as unfair by regulatees who do not regularly read the Federal Register. Second, Congress could ensure uniformity by mandating that enforcement actions take place only in the circuit in which the pre-enforcement appeal was heard. This solution seems awkward at best and very inconvenient at worst; it makes little sense to require an agency to try in the District of Columbia Circuit an enforcement case involving conduct occurring in California simply because the regulation under which the enforcement action arises survived judicial review in the District of Columbia Circuit.

261 See Justice on Appeax, supra note 250, at 170; Commission on Revision, supra note 250 , at 360 ; Currie \& Goodman, supra note 3 , at $73-74$. 
A compromise might be a statute that would vest exclusive venue for all appeals from administrative actions having "national significance" in a single court. Such a statute would reflect the policy judgment that here the percolation and signaling advantages of forum shopping must take a back seat to the need for national uniformity and business certainty. Congress has in fact attempted this approach in its most recent amendments to the Glean Air Act, which provide for exclusive review of actions that the Administrator finds to be of "nationwide scope or effect" by the District of Columbia Circuit. ${ }^{262}$ Unfortunately, terms like "national significance" and "nationwide scope or effect" still beg for wasteful threshold jurisdictional litigation. ${ }^{263}$ Congress could perhaps discourage some threshold litigation by providing, as it apparently did in the Clean Air Act, for the agency to make an unreviewable determination of "national significance." Private litigants, however, might oppose placing the threshold determination in the agency's hands on the ground that it would allow the agency to forum shop for review by the District of Columbia Circuit.

Despite the disadvantages of this compromise solution, it remains an attractive possibility. Congress has on many occasions vested exclusive review of administrative action in particular courts ${ }^{204}$ without an inordinant amount of threshold jurisdictional litigation. If only agency actions having nationwide scope or effect were reviewable in a single court the burden may not be as great as some commentators fear. Of 2,922 petitions for review of administrative agency proceedings filed in the federal appellate courts in fiscal 1979, over forty percent were petitions from NLRB and IRS actions, six percent were from the Immigration and Naturalization Service, and another five percent arose out of the occupational safety and health field. ${ }^{205}$ Practically none of these appeals involved an issue of nationwide scope or effect. ${ }^{200}$ Hence, easily fifty percent

26242 U.S.C.A. $\$ 7607$ (b) (1) (Supp. 1980).

263 Professor Currie suggests the case in which a national standard for gold mines has practical application only in three of the 11 circuits. Currie, supra note 6, at 1267. Such a standard would not have nationwide effect, but it would have nationwide scope, and would therefore seem to be reviewable only in the District of Columbia Circuit. This result, however, is certainly open to question.

264 See, e.g., 42 U.S.C. $\$ 4915$ (a) (1976) (exclusive review in District of Columbia Circuit of Noise Act standards); 42 U.S.C.A. $\$ 7607$ (b)(1) (Supp. 1980) (exclusive review in District of Columbia Circuit of certain Clean Air Act standards); 47 U.S.C. $\$ 402$ (b) (1976) (exclusive review in District of Columbia Circuit of FCC license denials).

265 AO REPORT, supra note 253 , at 49 , table 6.

266 Virtually all NLRB, IRS and INS appeals involve agency actions directed at individual employers, unions, taxpayers or aliens. Although some occupational safety and health appeals involve national regulations promulgated by OSHA, see 
of the petitions for administrative review filed last year did not involve actions having nationwide significance. Yet as many as 1,400 and probably more than 1,000 cases potentially did meet that test. The District of Columbia Circuit, the busiest circuit for administrative review, had only 666 administrative review petitions in 1979.267 Vesting that court with exclusive jurisdiction over appeals from agency actions of nationwide scope and effect could potentially double its administrative appeals caseload. On the other hand, if an entirely separate "administrative court" were created, its caseload of as high as 1,400 cases would be less than the total caseloads of seven of the eleven circuits. ${ }^{268}$ Nevertheless, because administrative appeals of national significance are generally more technical and time consuming than other appeals, many of which can be disposed of summarily, an administrative caseload of 1,0001,400 cases could be extraordinarily burdensome.

\section{b. Exclusive Venue in the Courts of the "Affected Regions"}

Congress could effectively reduce, though not eliminate, forum shopping by requiring transfer to a court of appeals according to a single criterion. A recently introduced bill, for example, would amend section 2112(a) to require the court in which the first petition was filed to determine whether a "substantial portion of the impact or injury" of the administrative action was in one or more judicial circuits; if so the court would be required to transfer to one of those circuits. ${ }^{269}$

Advantages accruing from such a proposal, however, are more apparent than real. Convenience of the parties, ${ }^{270}$ to the extent that it is a substantial concern, ${ }^{271}$ would be furthered only if at

29 U.S.C. $\$ 655(f)$ (1976), the bulk of the appeals are from the Occupational Safety and Health Review Commission, which adjudicates civil penalty actions directed at individual violations of OSHA standards or of the Act's general duty clause. See 29 U.S.C. $\$ 660$ (1976). This is not to say, of course, that individual determinations may not have precedential significance or nationwide scope and effect.

267 AO REPORT, supra note 253 , at 49.

268 Id. 44.

269 S. 739, 96th Cong., lst Sess. $\$ 3$ (1979). The Senate Judiciary Committee has reported a similar bill that would amend $\$ 2112(a)$ to list the regional impact of the agency action as a transfer criterion along with the convenience of the parties and the interest of justice. S. 2147, 96th Cong., 2d Sess. $\$ 218(\mathrm{c})(1980)$. See also H.R. 6782, 96th Cong., 2d Sess. (1980) (amending 28 U.S.C. $\$ 1391(\mathrm{e})$ (1976)).

270 See 125 Cong. Rec. S3188 (daily ed. March 22, 1979) (statement of Sen. Laxalt) [hereinafter cited as Laxalt Statement]; id. S9126 (daily ed. July 10, 1979) (statement of Sen. DeConcini) [hereinafter cited as DeConcini Statement].

271 See notes 153-58 supra \& accompanying text. 
least some of the parties were located in the chosen circuit. ${ }^{272}$ This is not necessarily the case. ${ }^{273}$ The percolation and signaling functions of multi-circuit review would not necessarily be preserved ${ }^{274}$ because the proposal might just as easily result in all appeals on a given issue being heard by a single circuit court of appeals. 275

Not only do the advantages of the "affected region" approach appear illusory, the scheme also has very authentic disadvantages. First, because the current proposals would merely amend the discretionary transfer section of section 2112(a) to make transfer nondiscretionary, they would preserve the race to the forum that makes the "affected region" determination. Litigants would probably view one court as more liberal than another in transferring under this test, and the race, with all its attendant costs, embarrassments, and threats to judicial comity, would thus survive, though perhaps in a somewhat attenuated form. This could be partially remedied by simply limiting venue in the first instance to "affected regions," but to the extent that the parties perceived differences between two circuits that met the "affected regions" test there would still be forum shopping attempts, and a mechanism would have to be devised to deal with them.

Even assuming no races to the courthouse, the proposals would guarantee that many client, government, and judicial resources would be expended in virtually every contested case in deciding whether "a substantial portion of the impact or injury" of the administrative action would occur in one or more circuits. ${ }^{276}$ For example, the proposal does not specify whose injury must be examined in deciding where the impact or injury occurs. While a substantial portion of the economic impact of a regulation limiting

272 Indeed, the proposed amendment to $\$ 2112(a)$ as written would apparently require transfer to a "substantially affected" circuit even if it did not have jurisdiction to hear the case. See Testimony of Assistant Attorney General James W. Moorman before the Subcommittee on Judicial Improvements of the Senate Judiciary Committee (Feb. 20, 1979), reprinted in Legal Times of Washington, Feb. 25, 1980, at 21, col. 1 [hereinafter cited as Moorman Testimony]. This defect, however, could be cured by providing only for transfer to a circuit in which a petition had been filed and in which jurisdiction was proper.

273 See, e.g., Moorman Testimony, supra note 272, at 22; Marcus, Environmentalists Lash Out at Bills Curbing D.C. Venue, Nat'l L.J., March 3, 1980, at 4, col. 2 (quoting William A. Butler, General Counsel of the Environmental Defense Fund).

274 See DeConcini Statement, supra note 270, at S9126.

275 For example, one can easily imagine the Tenth Circuit becoming, under the "regional impact" test, the exclusive circuit for review of all agency actions affecting the development of shale oil, because the vast bulk of shale oil reserves are located in Colorado, Utah and Wyoming.

276 See Moorman Testimony, supra note 272. 
sulfur dioxide emissions from new copper smelters would probably be in one or more of the western circuits, a substantial portion of the environmental injury due to acid rain caused by copper smelters could occur in one of the midwest or eastern circuits. Furthermore, the proposal provides no mechanism for determining which of two or more circuits that meet the test will hear the merits of the appeal. Hence, even after a court makes the threshold "affected region" determination, it may be required to make an additional, essentially discretionary, choice between two or more qualifying circuits. In sum, the "affected region" test would result in loosely confined threshold litigation, "precisely the kind of litigation that venue statutes are intended to avoid." 277

\section{Managing Forum Shopping}

Should Congress determine that the available mechanisms for reducing or eliminating forum shopping for review of administrative action are not feasible, it might still attempt to reduce or eliminate some of the more wasteful and unseemly aspects of the current practice under section 2112(a). At least two models for managing forum shopping are available. Congress could vest a single body with authority to decide, according to specified criteria, which of the available courts of appeals should decide the merits of the controversy. Alternatively, Congress could eliminate the need for any intermediate decisionmaker by specifying an automatic mechanism, such as a lottery or a nonperiodic rotation, for determining which of the available courts will hear the merits of an appeal.

\section{a. Discretionary Mechanisms: The Multi-district Panel Proposal}

Should Congress opt for a discretionary mechanism, it might adopt a recent proposal to lodge the threshold decision in a special panel such as the judicial panel on multi-district litigation. ${ }^{278}$ The

277 Currie, supra note 6 , at 1266.

Current proposals for vesting venue exclusively in circuits in which a substantial portion of the impact or injury occur are apparently designed solely to avoid the District of Columbia Circuit. See Laxalt Statement, supra note 270, at S3188 ("IT]he precedent in the District of Columbia Circuit more precisely reflects the attitudes of the Federal Government"); Statement of former Utah Governor Calvin L. Rampton, quoted in Marcus, supra note 273 , at A4, col. 2 ("It is difficult for a judge whose entire experience has been in water-abundant areas of the nation adequately to set in proper perspective the evidence and law if he has no exposure to the ... water-short areas of our nation.").

278 See Ross \& Goldman, supra note 42, at 27, col. 1; Haworth, Modest Proposals to Smooth the Track for the Race to the Courthouse, 48 Geo. WAsh. L. Rev. 
judicial panel on multi-district litigation presently consists of "seven circuit and district judges designated from time to time by the Chief Justice of the United States, no two of whom shall be from the same circuit." 279 The business of that panel is to transfer civil actions "involving one or more common questions of fact" 280 that have been filed in two or more district courts to a single court for the conduct of pretrial proceedings. Congress established the panel to increase judicial efficiency in supervising pretrial activities, to eliminate the potential for conflicting district court pretrial rulings, and to reduce inconvenience to parties and witnesses. ${ }^{281}$ Although these do not precisely coincide with the purposes of section 2112(a), the multi-district panel plays a role that is similar to that of a circuit court deciding the discretionary transfer question under that section. Congress might, therefore, simply eliminate the first-to-file rule and instead require that all petitions that have been filed in more than one court during the statutory filing period be transferred initially to the panel on multi-district litigation for retransfer according to specified criteria. ${ }^{282}$

This relatively simple mechanism would eliminate the race to the courthouse with its attendant expense, potential for unfairness, and embarrassment, because there would be no advantage in being the first to file. The proposal also provides a convenient solution to the "same order" problem, because the pendency of the same or

211 (1980); Office for Improvements in the Administration of Justice, U.S. Dep't of Justice, Proposal for Improvements in the Federal Appellate Courts, Proposal 7, at 2 (June 21, 1978) [hereinafter cited as Justice Department Proposal]; Letter from Wm. Warfield Ross to Richard K. Berg, Executive Secretary, Administrative Conference of the United States (Jan. 10, 1980) (on file at U. PA. L. Rev.) [hereinafter cited as Ross Letter]. Ross and Goldman make two alternative proposals for ending the race to the courthouse [hereinafter referred to as "Ross Proposal 1" and "Ross Proposal 2"]. Ross Proposal 1, relevant here, would have the panel on multi-district litigation determine which circuit should hear the merits based on a consideration of the following factors:

(i) the interest of the party most aggrieved by the agency order, (ii) the pendency of related proceedings, (iii) the local nature of the subject matter of the agency order, and (iv) the interest of the public at large; or where none of the foregoing are relevant, by (i) the facilitation of judicial administration and (ii) such other considerations as may be relevant.

Id. 3-4.

Ross Proposal 2 would have the agency choose the forum on the basis of the same considerations.

27928 U.S.C. $\$ 1407$ (d) (1976).

280 Id. $\$ 1407(\mathrm{a})$.

281 See Comment, The Experience of Transferee Courts under the Multidistrict Litigation Act, 39 U. CHI. L. Rev. 588, 590-91 (1972). In actual practice the transfer has often resulted in the case coming to its conclusion in the transferee court. Id. 607-09.

282 See Ross Proposal 1, supra note 278. 
interrelated proceedings in one circuit could be one of the criteria for transfer. Finally, if Congress were willing to give the multidistrict panel the authority to issue stays pending resolution of the threshold question, this proposal could also solve the problem of temporary stays. 283

The proposal, on the other hand, does not necessarily secure uniform application of national policy and reduce business uncertainty, because it would still allow forum shopping. The proposal would only eliminate the initial race; the parties would still have the opportunity, and in fact the obligation, to press for discretionary transfer. Unless one of the criteria for transfer is the potential of the transferee court to ensure uniformity, a criterion that is not listed in any of the current proposals, ${ }^{284}$ the panel approach would not be expected to further the uniformity and business certainty policies. By the same token, the proposal has the corresponding advantage of preserving the percolation and signaling advantages of multi-circuit review.

The greatest disadvantage of the independent panel approach to deciding the threshold question is its potential to consume large amounts of client and judicial resources. While the proposal would eliminate the expense of the race, it would probably increase the cost of discretionary transfer litigation. In many cases under section 2112(a) the parties do not press for discretionary transfer once the outcome of the race has been determined. The panel proposal, however, would guarantee threshold litigation in every case in which two petitions are filed in different circuits. Moreover, the criteria for transfer, ${ }^{285}$ while similar to those articulated by the courts in section 2112(a) litigation, ${ }^{286}$ are extremely malleable and hence subject to intense dispute on a case-by-case basis. ${ }^{287}$ Even though only a single panel would decide such cases, it is unlikely that a wellsettled "law of discretionary transfer" would ever evolve. Furthermore, some of the suggested criteria, such as the relative aggrievement of the parties and the local nature of the subject matter, would

283 See notes 201-04 supra \& accompanying text.

284 Ross Proposal 1 lists "the interest of the public at large" as a criterion. Conceivably the interest of the public at large would be furthered by the uniform application of national policy. One could more directly ensure consideration of this policy by listing as a criterion "the potential of the transferee court to ensure uniformity." See note 278 supra.

285 See note 284 supra.

286 See notes 150-200 supra \& accompanying text.

287 In fact, enterprising attorneys are sure to turn these transfer criteria into a charade by disingenuously arguing that justice or convenience requires transfer when their sole motivation for so arguing is the desire to have the merits heard in a friendlier forum. See note 42 supra. 
occasionally call for factual inquiries or at the very least for timeconsuming scrutiny of the administrative record. Finally, the combination of the amount and intensity of the litigation that could be expected to result from the proposal's adoption would virtually guarantee that the panel could not expeditiously dispose of the transfer cases. Briefing, arguing, and deciding such cases could consume months. In addition to the direct costs of the proceedings, the delay itself could in many cases cause great loss to one or more of the parties. ${ }^{288}$

\section{b. Discretionary Mechanisms: Transfer Criteria}

In spite of these flaws, Congress could still choose a discretionary transfer mechanism as a partial solution to the forum shopping problem. The success or failure of such a mechanism might depend upon the effectiveness and faimess of the criteria chosen to guide the multi-district panel in making the transfer determination. It is therefore necessary to examine several recently proposed criteria, most of which have already been suggested by the courts in deciding cases under section 2112(a).

\section{(i) Judicial Expertise}

The recent proposal that the "application of judicial expertise" be a criterion for ordering discretionary transfer ${ }^{289}$ is as novel as it is intriguing. The courts have consistently refused to adopt the concept of "specialization of tribunals." 290 Yet adopting "judicial expertise" as a criterion for transfer would inevitably lead the courts in the direction of specialization. After a court had decided one or two cases under a particular regulatory scheme, it could expect, other things being equal and venue being proper, to receive subsequent cases under the same regulatory scheme.

Applying "judicial expertise" as a transfer criterion could have several advantages. Allowing the judges that have familiarized themselves with a regulatory scheme to continue to hear cases arising out of that scheme could increase judicial efficiency. Under

288 See Fels, supra note 85 , at 49 . The identity of the party harmed by the litigation delay would depend upon whether or not the agency or the multi-district panel stayed the effectiveness of the agency action. In either case delay could have a financial or physical impact on at least one of the parties.

289 See Justice Department Proposal, supra note 278, at 3; Note, Venue for Judicial Review of Administrative Actions: A New Approach, 93 HAav. L. Rev. 1735 (1980).

290 See note 174 supra. 
present court of appeals assignment policies, however, this purported advantage of "judicial expertise" transfer is illusory, because there is no guarantee that the same panel in the transferee circuit would hear all appeals arising out of a single statutory scheme or even out of a single administrative proceeding. ${ }^{291}$ Obviously it would take a large number of cases to ensure that all of the judges in a circuit acquired expertise in the ins and outs of a regulatory scheme. A given panel could probably learn as much from the experience of a panel in another circuit as it could learn from the experience of a panel in its own circuit. Apart from its experience in deciding cases under a statutory scheme, there is no reason to suppose that one court of appeals is likely to have more "judicial expertise" than another. There is little indication that any judge is chosen for a particular circuit because his or her background indicates an expertise that might be useful in that circuit. Hence, the whole concept of "judicial expertise" lacks any practical meaning in a system in which courts are composed of many generalist judges, any three of whom may hear a given case on a given day.

If "judicial expertise" were nevertheless adopted as a criterion the multi-district panel could ignore the above objections and simply impose specialization by brute force. All FCC and EPA cases might be sent to the District of Columbia Circuit because that circuit already is required by statute to hear many cases arising from those agencies. ${ }^{292}$ All SEC cases could be sent to the Second Circuit, because that circuit includes Wall Street. Department of Interior and Park Service cases could be routed to the Tenth Circuit, energy cases to the Fifth Circuit and so on. After a sufficient number of transfers the courts might indeed become expert tribunals. But this is not guaranteed, because there is no assurance that venue will always, or even usually, be proper in the "expert" circuit.293 Additionally, to the extent that the "judicial expertise" criterion, where applicable, did not always prevail over the other discretionary criteria, still further transfers could go to "nonexpert" circuits.

Assuming that expert courts would nevertheless evolve, it is certainly debatable whether the advantages of the resulting system would outweigh its disadvantages. The "expert" courts could potentially acquire the same narrowness of view and biased perspective that argues against the proposal for vesting exclusive venue in a

291 This point has been largely ignored by the critics of agency relitigation.

292 See note 264 supra.

293 Venue is generally determined by reference to the particular agency statute. See note 40 supra. 
single court. ${ }^{294}$ In any event, that balance is probably best struck by Congress in individual venue statutes and not by a multi-district panel applying a "judicial expertise" criterion.

\section{(ii) Pendency of Same or Similar Proceeding}

If the first of two successive orders is currently pending in one court of appeals at the time the multi-district panel is required to decide where to lodge the subsequent order, the panel obviously should take that factor into consideration. Indeed, under the "same or interrelated proceedings" test for the definition of the "same order," ${ }^{295}$ this should be the only criterion applied. To advance judicial economy and to eliminate the threat of inconsistent rulings on the "same order," the multi-district panel should follow the current practice of the circuit courts ${ }^{296}$ and transfer the proceeding to the court in which an appeal concerning the "same order" is currently pending. The cases would then presumably be consolidated for a single decision by a single panel. In addition, the previous suggestion that the agencies adopt the practice of specifying whether simultaneous or successive orders are the "same order" is equally applicable here. ${ }^{297}$

The considerations, however, are different when the first court has already decided a case involving similar issues or when a petition that does not involve the "same order" is currently pending before another court. In neither of these cases would consolidation necessarily preserve judicial economy. As previously discussed, ${ }^{298}$ there is no guarantee that the same panel in the transferee circuit would hear both cases. Moreover, especially when a prior decision has already been rendered, failure to transfer poses no threat to judicial comity, because by definition the proceedings do not involve the same agency action. The second court might reject the first court's reasoning, but it theoretically would not be directly contradicting the mandate of the prior circuit.

\section{(iii) Comparative Aggrievement}

The courts of appeals in two cases have ordered discretionary transfer on the ground that the first petitioner was not sufficiently

294 See text accompanying note 259 supra.

${ }^{295}$ See notes 137-49 supra \& accompanying text. There appears to be no good reason why the "same or interrelated proceedings" test would not prove as serviceable to the multi-district panel as it has been to the courts of appeals.

296 See text accompanying notes $137-44$ supra.

297 See text accompanying notes $245-49$ supra.

298 See text accompanying notes $145-49$ supra. 
"aggrieved" by the agency's action.299 However, the courts have on many occasions stated that this ground should only be used where the "inconsequential" character of the petitioner's aggrievement is clear from the petitioner's own stipulation, pleading or representation. ${ }^{300}$ Despite the courts' past reluctance to rely upon this criterion, "the interest of the party most aggrieved" has been suggested as a criterion for use by the multi-district panel in deciding upon the appropriate transferee court. ${ }^{301}$

Listing "comparative aggrievement" as a transfer criterion would discourage some forum shopping by parties who were substantial winners at the agency level. It would likewise implement the policy currently underlying section 2112(a) of preventing the agency from choosing the forum. If "comparative aggrievement" were a criterion, a party would have no incentive to intervene in the administrative proceeding on the side of the agency staff solely for the purpose of choosing a review forum that was believed to be sympathetic to the agency's position. Judicial insistence that a petitioner have standing does not really remedy the problem of frivolous forum shopping petitions, because the standing determination is usually made after the court has accepted jurisdiction and has begun deciding the merits of the controversy. Because the court will generally not dismiss the case on the ground that one party lacks standing so long as its opponent is aggrieved by the agency decision, the unaggrieved petitioner can as a practical matter pick the forum in the absence of a mechanism that weeds out frivolous petitions at the outset.

While it may make sense to penalize an unaggrieved petitioner by denying it the forum of its choice, it makes much less sense to advocate that the relative "aggrievements" of the various petitioners be examined as a threshold matter. Such an examination would require the body making the threshold determination to launch a detailed and.probing inquiry into the merits of the controversy. The experience of the court in Insurance Workers International Union $v$. $N L R B{ }^{302}$ should adequately demonstrate the extent to which a court must explore the proceedings below in order to apply this criterion, even in easy cases in which the petitioner's claim to

299 See note 163 supra.

300 See notes 167-68 supra \& accompanying text.

301 See Ross Proposal 1, supra note 278. See also Justice Department Proposal, supra note 278 , at 3 . supra.

302360 F.2d 823 (D.C. Cir. 1966). See text accompanying notes 164-68 
have standing is very tenuous. Requiring the courts to ascertain the party "most aggrieved" by the agency action, however, goes far beyond even Insurance Workers. That court only decided that an unaggrieved party should not have its choice of forum. The facts did not require the court to examine the aggrievement of the other petitioners. Making comparative aggrievement a criterion for discretionary transfer would require a threshold look at the alleged aggrievement of all petitioners. It would also invariably require value judgments as to the nature and extent of petitioners' harms. In International Union Department $v$. Bingham, ${ }^{303}$ for example, the petroleum industry petitioners alleged that their aggrievement was far more substantial than that of the union. The petroleum industry stood to lose half-a-billion dollars if OSHA's benzene standard were upheld, whereas the union's complaint with the standard was that it did not go far enough in protecting benzene workers. Even though the union agreed with the agency action in almost all particulars its position was that the agency's failure to adopt the union's position in its entirety could result in the risk of additional deaths among benzene workers, an "aggrievement" that, if true, would appear to be substantial under any conceivable test. The petroleum industry petitioners, of course, disagreed. But, as Judge Leventhal recognized, a threshold hearing on discretionary transfer is hardly the place for resolving these weighty contentions.

Congress could perhaps preclude extensive threshold inquiries into aggrievement while at the same time preserving the multidistrict panel's discretion to refuse to honor requests for transfer by frivolous petitioners by writing that requirement into the statute as a strict "nonaggrievement" rule, rather than by listing comparative aggrievement as a criterion. Congress could probably accomplish this by providing that the multi-district panel refuse even to consider petitions that were facially inadequate to establish aggrievement with the agency's decision. This would amount simply to a statutory adoption of the rule that has already evolved in the appellate courts under section 2112(a). Even this relatively limited inquiry, however, will require a threshold scrutiny of the petitions, the agency decision, and perhaps the agency record. It could likewise involve briefs and perhaps oral argument. Because inventive counsel can usually find some substantial point on which to disagree with an agency decision, this suggested nonaggrievement rule would probably be successfully invoked only rarely. In the final analysis its benefits may not justify its costs. 


\section{(iv) Regional Nature of the Problem}

This Article has already examined proposals that cases be automatically transferred to the circuit containing the "most affected region." 304 Other proposals have stopped short of making "regionality" the only criterion for transfer, but have listed it as one of several criteria. ${ }^{305}$ Although the advantages and disadvantages of considering regionality as a threshold matter are attenuated when it is only one of many criteria, the considerations are the same and will not be recapitulated here, except to point out that consideration of this criterion will involve still further time and expense for the parties and the multi-district panel.

\section{(v) Convenience of the Parties}

As previously discussed, in most appeals from nationally applicable administrative action, the convenience of the parties is not a relevant consideration. ${ }^{306}$ Nevertheless, one can imagine cases, such as between a large employer and a small union or a large union and a small employer, in which convenience might play a role. Listing "convenience of the parties" as a criterion would preserve the multi-district panel's option to transfer in the relatively rare cases in which the inconvenience to one of the parties outweighs the other criteria.

\section{(vi) Convenience of the Courts}

The fact that lawyers sometimes consult the status of the dockets of the courts where venue is proper indicates that the desire for rapid resolution of a controversy can outweigh any perceived advantage attributable to a court's reputation or general outlook. ${ }^{307}$ The need for expeditious resolution of cases is a relevant consideration for the courts as well. Although no court has ever explicitly relied upon the status of the docket of the potential transferee courts as a reason for transfer, ${ }^{308}$ "sound judicial administration" has been

304 See notes 269-77 supra \& accompanying text.

305 Justice Department Proposal, supra note 278, at 3; Ross Proposal 1, supra note 278.

306 See notes 153-58 supra \& accompanying text.

307 Two out of 18 relevant responses to the author's survey letter mentioned this as a criterion of choice. See note 42 supra.

308 The court in United Steelworkers v. Marshall, 592 F.2d 693, 697 (3d Cir. 1979), suggested "the relative state of the dockets" as a possible transfer criterion, but did not apply it in that case because all of the convenient courts of appeals had crowded dockets. 
suggested as a possible criterion for transfer. ${ }^{309}$ The multi-district panel would be in a good position to apply this criterion, because it could objectively assess the respective backlogs of the relevant courts. No searching inquiry of the administrative record would be necessary.

The proposed criterion could, however, have the effect of systematically routing most administrative cases in the direction of some courts and away from others. For example, at the end of fiscal 1979, seventy-five cases per judgeship were pending before the Second Circuit, while 123, 116, 167, 148, and 176 cases per judgeship were pending in the District of Columbia, Third, Fourth, Fifth and Ninth Circuits, respectively. ${ }^{310}$ The same general disparity holds for fiscal 1978.311 Application of the "judicial administration" criterion alone in those years would presumably have resulted in a net shift of administrative cases out of the District of Columbia, Third, Fourth, Fifth and Ninth Circuits and into the Second Gircuit, even though the Second Circuit received more filings per authorized judgeship than all but the Fourth Circuit in 1979 and all but the Fourth, Fifth, and Ninth Gircuits in 1978. One can legitimately question whether a court that keeps up with its docket should be thus penalized.

\section{c. Automatic Mechanisms}

Rather than giving some body authority to assign cases among the available circuits, Congress could provide an automatic, nondiscretionary mechanism for assigning cases in which multiple petitions have been filed in the same manner that judges are assigned to panels within the circuits. ${ }^{312}$ In choosing an automatic mechanism, Congress would need only ensure that its outcomes were not predictable. A simple lottery would probably be the easiest automatic mechanism, or a neutral assigning body, such as the Adminis-

309 Justice Department Proposal, supra note 278, at 3; Ross Proposal 1, supra note 278.

310 AO REPORT, supra note 253 , at 45 , table 3.

$311 \mathrm{Id}$.

312 See Public Serv. Comm'n v. FPC, 472 F.2d 1270, 1272-73 (D.C. Cir. 1972). Lotteries are used for a number of important decisions where more appropriate criteria are elusive, such as the draft for induction into military service, see United States v. Kotrlik, 465 F.2d 976 (9th Cir.), cert. denied, 409 U.S. 1043 (1972), and the assignment of public housing, see Holmes v. New York City Housing Authority, 398 F.2d 262, 265 (2d Cir. 1968). The Federal Communications Commisison has recently instructed its staff to draft a proposed opinion for assigning by lottery a broadcast license between two licensees that are otherwise "equally qualified." See Broadcasting, June 9, 1980, at 30, col. 1. 
trative Office of the United States Courts, could assign cases in some other random fashion.

An automatic mechanism would avoid costly courthouse races, eliminate the need for costly threshold discretionary transfer litigation, ${ }^{313}$ and satisfy most conceptions of fairness. No party would have any particular advantage, because the choice would be utterly impartial. ${ }^{314}$ The starting-pistol problems of section 2112(a) practice would similarly disappear, because all parties would have until the end of a predetermined period to file petitions for review. This should also encourage parties to file thorough petitions for review rather than the prefabricated skeletal outlines that are typical in races to the courthouse. ${ }^{315}$ Although the public might be unfavorably impressed by a system which necessitates a lottery or random schedule to allocate cases among presumably neutral forums, the automatic mechanism would virtually eliminate section 2112(a)'s potential for drawing sustained public ridicule. At the same time an automatic mechanism would preserve judicial comity, because the mechanism would avoid any possibility that two courts would be required to decide the same question in the same case. Finally, an automatic mechanism would preserve the percolation and signaling benefits of forum shopping.

Like all forum-allocating mechanisms, the automatic mechanism has its disadvantages, including its failure to encourage uniform application of agency-administered laws and its propensity to perpetuate business uncertainty. The agency and affected businesses can similarly never know in advance how deferential the reviewing court is likely to be toward the agency's factual findings and policy-dominated inferences. To a large extent, however, these disadvantages are an inevitable trade-off that must be suffered in a system that merely controls rather than eliminates forum shopping.

The "pure" automatic mechanism proposal is likely to prove unattractive to many lawyers because of its inherent inflexibility. In order to ensure a properly functioning "pure" automatic mechanism Congress would have to take away from the courts the power to transfer a case once the mechanism had assigned the case to that court. Although it is difficult to imagine a case in which

313 Cf. Navarro Sav. Ass'n v. Lee, 100 S. Ct. 1779, 1783 n.13 (1980) (arguing that it is more important to have a rule that avoids threshold litigation than it is to have a less arbitrary procedure).

314 See G. Calabresi \& P. Bobbitt, Tragic Chotces 41-44 (1977); Fels, supra note 85 , at 50-51.

315 See text accompanying note 7 supra. 
this inflexibility could prove to be inefficient or unfair, the mechanism makes no allowance for such cases. If some flexibility is desired, Congress could retain the flexibility of the existing system -while eliminating most of its unsavory aspects-by allowing the court to which a case is originally assigned to transfer to any other court "in the interest of justice for the convenience of the parties." This proposal would merely eliminate the race; forum shopping could still occur at the discretionary transfer stage.

The obvious disadvantage of this "hybrid" automatic/discretionary model is its propensity to encourage wasteful threshold litigation over discretionary transfer. The previous analysis of the courts' experience in implementing section 2112(a)'s discretionary transfer provision indicates that the transfer criteria rarely point to a single court in a given case. Yet as long as the courts remain relatively generous in granting motions to transfer, the parties to administrative appeals will have an incentive to litigate that question, however inefficient that process might be from an overall societal perspective. Congress might well decide that the costs of this round of threshold litigation outweigh any capacity it might have for preserving fairness in those rare cases in which justice and convenience clearly point to a single court. ${ }^{316}$

316 Even if Congress adopted the "pure" automatic assignment mechanism, it might desire to retain sufficient flexibility to deal with the "same order" problem. See notes 128-49 supra \& accompanying text. If all petitions from a given order are determined by an automatic mechanism, then there would appear to be no discretion to allow a single court to decide questions involving simultaneous or successive orders that are in fact the "same order." This defect could be eliminated by giving some body jurisdiction to order consolidation under the "same or interrelated proceedings" rule. See text accompanying notes 184-88 supra. The ideal body to make this determination is the agency, because it is familiar with its procedures and with the details of the proceedings from which appeals are taken. The Administrative Office of the United States Courts could be required to determine intercircuit petitions by an automatic mechanism except in cases in which the agency certified to the Administrative Office that several orders simultaneously issued were in fact the "same order," in which case the Administrative Office would consolidate all of the petitions and send them to a single circuit. For successive orders, the Administrative Office could be instructed to transfer to the court in which the agency determined that the "same order" is being decided.

Because this suggestion for resolving the "same order" problem appears to allow the agency to engage in forum shopping, see text following note 248 supra, it may not be politically feasible to enact a statute that provides for consolidation of cases involving the same order by any body of lesser status than a court. The proposal might therefore be modified to require the court receiving the second of two allegedly successive orders to transfer to the court currently hearing the first such order under the stringent "same or interrelated proceedings" rule. See notes 184-88 supra \& accompanying text. A stringent rule would be required to prevent undue threshold litigation over whether two successive orders were in fact the "same order." In no case should transfer be allowed when the first court has already decided the first case, because such transfer would of necessity recognize a theory of specialized tribunals that Congress, in adopting the automatic mechanism, must have rejected. Finally, the Administrative Office could consolidate all 
Another problem that proposals for an automatic mechanism must address is the timing of the mechanism and the related question of the issuance of stays of administrative action pending review on the merits. ${ }^{317}$ Congress could, of course, essentially eliminate the stay problem by mandating that the Administrative Office choose a forum for the merits within twenty-four hours of the filing of the first petition for review. Because stays are rarely necessary within a day after the agency action, this would in effect assign the stay decision to the court that hears the merits. ${ }^{318}$ For the extremely rare case in which a stay is necessary within twentyfour hours any court of appeals in which a petition was filed could retain jurisdiction to issue twenty-four hour stays pending assignment of the case.

The difficulty with the twenty-four hour assignment is the fact that the case could be assigned before all potential litigants would normally be aware of the fact that the agency had acted. To avoid missing the deadline parties would still have to employ paralegals to stalk the Federal Register Office, ${ }^{319}$ and lawyers would still be required to file hastily drafted petitions as rapidly as possible. There would thus be a race, but it would be more in the nature of a qualifying heat.

Congress could alternatively provide sufficient time (approximately ten days) for all potential litigants to receive notice of the agency's action before the case would be assigned to a particular circuit. This proposal, however, reintroduces the requirement that some body be vested with authority to issue emergency stays. ${ }^{320}$

appeals from simultaneous orders and assign them to a single court which would then be required to refer back to that Office for reassignment those orders that were not, according to the court, the "same order." Again, the courts should be encouraged to be niggardly in referring matters back to the Administrative Office so as to discourage threshold litigation.

In the final analysis, the relatively rare cases in which the "same order" question arises may not warrant this much intrusion into the automatic assignment process.

317 See notes 201-04 supra \& accompanying text.

318 All parties that filed timely petitions would, of course, be allowed to participate in the appeal. The 24-hour cut-off would merely limit the possible forums to those in which petitions had been filed within that time limit.

319 See text accompanying note 104 supra.

$320 \mathrm{This}$ alternative would also hinder the not atypical practice of ordering expedited briefing schedules for the merits of the case after stays have been issued, because the court issuing the stay would not necessarily be the court deciding the merits. However, the court deciding the merits could just as easily order an expedited briefing schedule. The eight or nine days lost awaiting assignment of the case should not seriously interfere with an expeditious resolution of the merits. In any event, if 10 days are needed to give notice to all potential litigants, a briefing schedule that penalized those parties that did not petition for review within that time period would seem fundamentally unfair. 
If such authority were granted to the court in which the party seeking the stay filed its petition, a race to the stay-issuing court, with all its attendant disadvantages, would be the likely result.

This residual race could be eliminated in one of two ways. The administrative agency could state that its order did not become effective until after the court of review has been assigned. ${ }^{321}$ This would eliminate entirely the rationale for the race. Alternatively, Congress could vest jurisdiction for issuing temporary stays in the Temporary Emergency Court of Appeals, ${ }^{322}$ and mandate that any stays thereby granted automatically dissolve within a few days after the circuit of review has been assigned. Although utilizing the Temporary Emergency Court of Appeals in this manner may increase litigant and judicial costs by requiring the litigation of two temporary stays, there would still be marked cost savings overall. Not only is it unlikely that the fight for and against the second stay would require much extra effort, ${ }^{323}$ but the single most costly component of the struggle-the race and its attendant litigation-would be eliminated.

Finally, the automatic system does not preclude the possibility of forum shopping to avoid a particular circuit. This problem seems ultimately unsolvable. In the energy area in particular, attorneys representing producers appear to be more concerned with avoiding the District of Columbia Circuit than with locating their appeals in any one of the other circuits. ${ }^{324}$ A large multi-state corporation could under many venue statutes substantially increase its chances of avoiding a particular court by filing petitions in all of the other circuits. In any given case the probability of the case being heard in the circuit that it sought to avoid would be only one-in-eleven. This might be perceived as an unfair advantage to the large corporation that can file petitions in many circuits. Congress could reduce the impact of this ploy somewhat by providing that a single petitioner could file only one petition for review, but this rule could easily be circumvented in the typical rulemaking proceeding in which numerous parties are lined up on either side of a given issue.

321 For instance, the recently promulgated EPA race regulations state that an order is not "promulgated" until two weeks after its publication in the Federal Register. See Final EPA Race Regulations, supra note 17, at 26,046.

322 See generally 17 WRGGr \& MHLER, supra note 4, at $\$ 4105$; Nathanson, supra note 250 , at 1009-12.

323 See note 320 supra.

324 Confidential communications to the author. See note 42 supra. 


\section{CONCLUSION}

The author readily admits that the proposal espoused here, an automatic mechanism for the assignment of agency appeals, will be resisted despite its apparent fairness and simplicity. The idea of such a mechanism runs directly against the lawyer's deeply ingrained weltanschauung, the notion that every question has a correct answer that can best be reached through adversial procedures. The burden in this case, however, should be upon those who, perhaps self-servingly, argue that large amounts of society's limited resources should be devoted to the essentially trivial question of which of two co-equal courts shall hear a particular appeal. While the automatic mechanism in some rare cases may work a hardship upon one who cannot afford to send a lawyer to a distant appellate court, that relatively minor disadvantage is more than offset by the vast amount of legal energy that can be conserved by the simple roll of a die. 